Historic, archived document

Do not assume content reflects current scientific knowledge, policies, or practices. 

Forest

Service

North Central

Forest Experiment

Station

Resource Bulletin NC-155

UAS

Forest Statistics for Michigan's Southern Lower Peninsula Unit, 1993

Thomas L. Schmidt

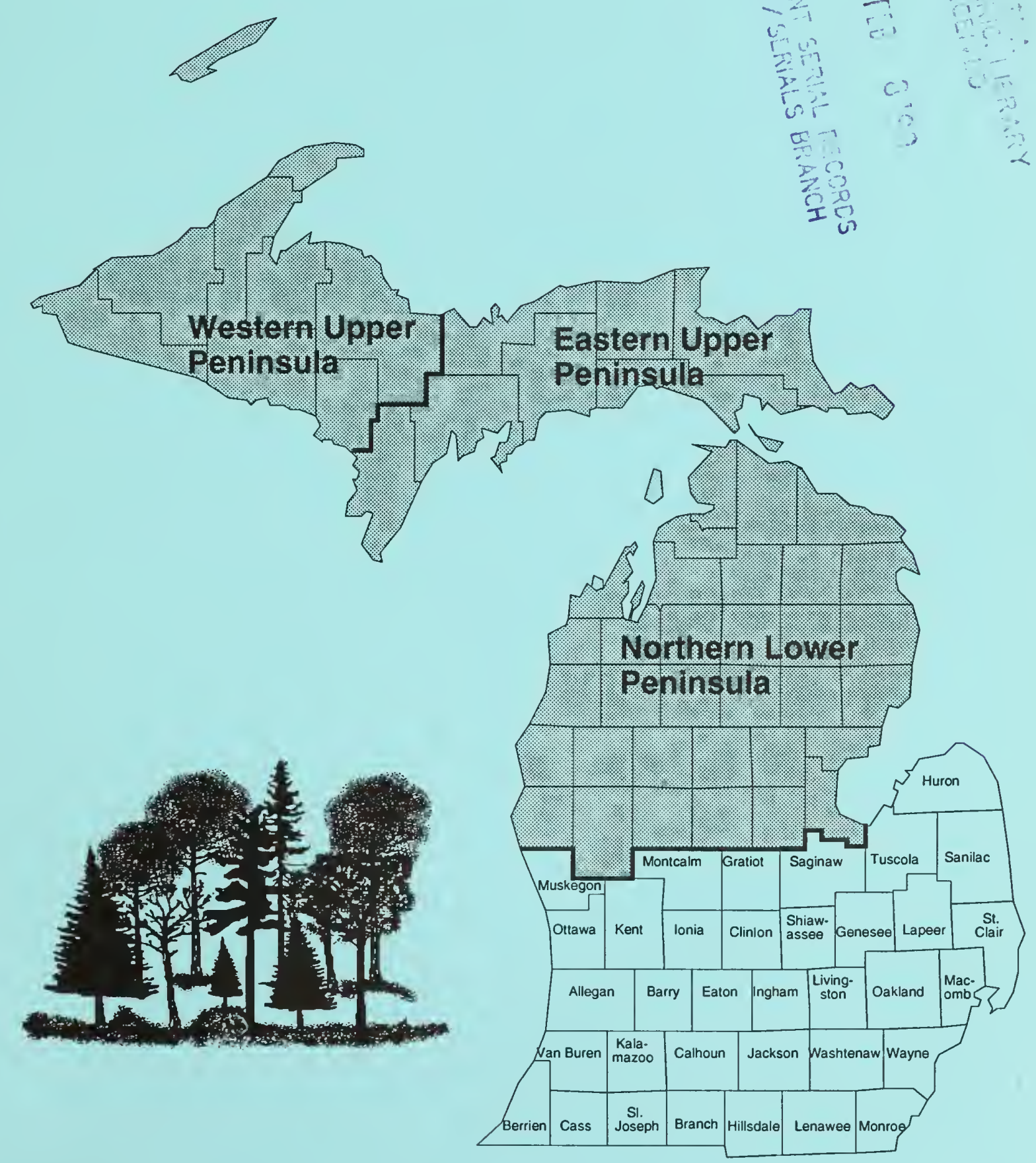


This report includes the most commonly used U.S. Department of Agriculture, Forest Service, Forest Inventory and Analysis (FIA) statistics. Additional forest resource data can be provided to interested users. Persons requesting additional information from the raw inventory data are expected to pay the retrieval costs. These costs range from less than $\$ 100$ for a relatively simple request to more than $\$ 2,000$ for a complex retrieval involving the services of a Forest Inventory and Analysis computer programmer. Requests will be filled so as to minimize the impact on the Forest Inventory and Analysis Work Unit.

Requests for information may be directed to:

Program Manager

Forest Inventory and Analysis

North Central Forest Experiment Station

1992 Folwell Avenue

St. Paul, Minnesota 55108

Phone: (612) 649-5139

or

State Forester

Michigan Department of Natural Resources

Forestry Division

P.O. Box 30028

Lansing, Michigan 48909

Phone: (517) 373-1275

Area served: Illinois, Indiana, Iowa, Kansas, Michigan, Minnesota, Missouri, Nebraska, North Dakota, South Dakota, Wisconsin. 


\section{FOREWORD}

Forest Inventory and Analysis (FLA) is a continuing endeavor as mandated by the Renewable Resources Research Act of 1978. Prior inventories were mandated by the McSweeney-McNary Forest Research Act of 1928. The objective of FLA is to periodically inventory the Nation's forest land to determine its extent, condition, and volume of timber, growth, and removals. Up-to-date resource information is essential to frame forest policies and programs. USDA Forest Service regional experiment stations are responsible for conducting these inventories and publishing summary reports for individual States. The North Central Forest Experiment Station is responsible for forest inventory and analysis in Illinois, Indiana, lowa, Kansas, Michigan, Minnesota, Missouri, Nebraska, North Dakota, South Dakota, and Wisconsin.

Fieldwork for the fifth forest inventory of Michigan's Southern Lower Peninsula Unit was begun in September of 1992 and completed in August of 1993. Reports of the four previous inventories of Michigan's timber resource are dated 1935, 1955, 1966, and 1980.

To aid in determining current timber removals, the Michigan Department of Natural Resources (MiDNR) surveyed primary wood-using plants in the State. Aerial photographs used were black and white, infrared taken in 1986 at a scale of $1: 15,840$ (nominal). These photographs were purchased by MiDNR and loaned to the USDA Forest Service. 


\section{Contents}

Page

Highlights ........................................................................... 1

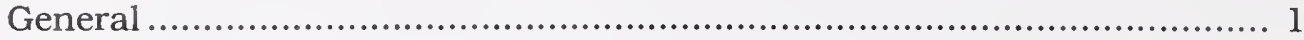

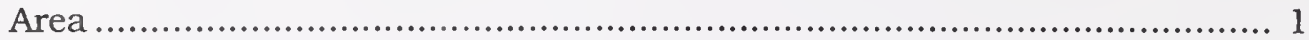

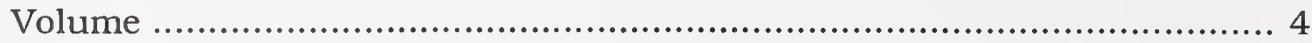

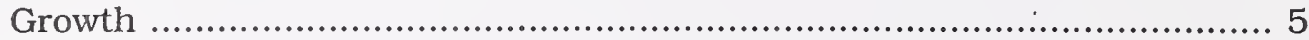

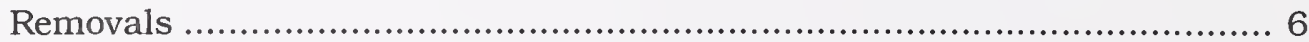

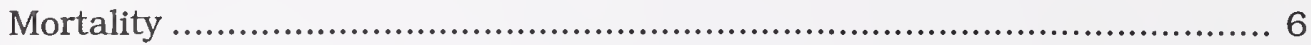

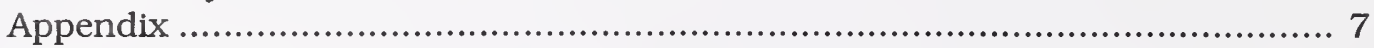

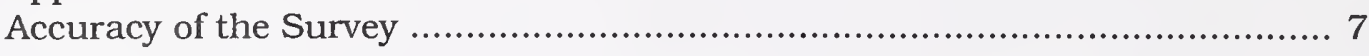

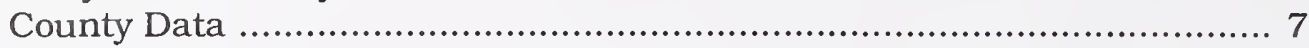

Comparing the Fifth Inventory of the Southern Lower Peninsula

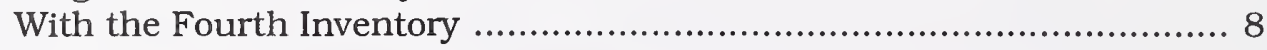

Survey Procedures ...................................................................... 8

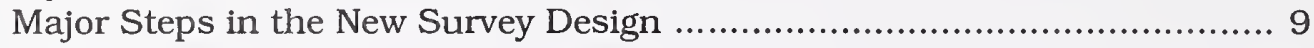

Tree and Log Grades .............................................................. 11

Metric Equivalents of Units Used in This Report................................. 14

Tree Species Groups in Michigan's Southern Lower Peninsula ..................... 14

Definition of Terms ................................................................... 15

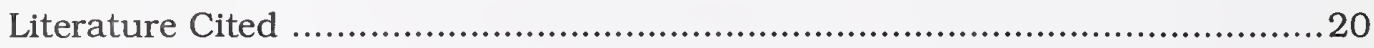

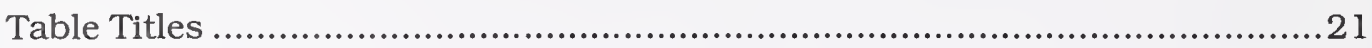

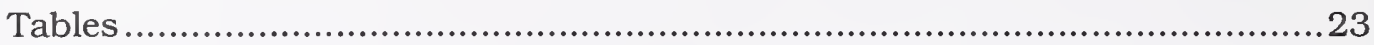




\title{
Forest Statistics For Michigan's Southern Lower Peninsula Unit, 1993
}

\author{
Thomas L. Schmidt
}

\section{HIGHLIGHTS}

NOTE: Data from new forest inventories are often compared with data from earlier inventories to determine trends in forest resources. However, for the comparisons to be valid, the procedures used in the two inventories must be similar. As a result of our ongoing efforts to improve the inventory's efficiency and reliability, we have made several changes in procedures and definitions since the last Michigan inventory in 1980. Because some of these changes make it inappropriate to directly compare the 1993 data with those published for 1980, data from the 1980 inventory have been re-processed using the current procedures.

Forest inventories completed before 1980 have not been adjusted to reflect current FIA inventory methodology and techniques. Comparisons between inventories should be general and used solely for analyzing trends.

All area and volume data and tables were based on what existed as of January 1, 1993, in the Southern Lower Peninsula of Michigan. The time period used for growth, mortality, and removals was January 1, 1980, to December 31,1992 . The area of census water recorded for this unit increased from 198,400 acres in 1980 to 4,603,400 acres in 1993 as major portions of the Great Lakes were allocated to the total area for this unit by the U.S. Bureau of

Thomas L. Schmidt is a Research Forester in the Forest Inventory and Analysis Program at the North Central Forest Experiment Station, St. Paul, Minnesota. He received a bachelor's degree in forest management in 1976 and a master's degree in forestry/land-use planning in 1981 from the University of MissouriColumbia. He received his Ph.D. in agronomy/ecology from the University of Nebraska-Lincoln in 1991 and joined the Forest Service in 1992. the Census. The data in this report are subject to change when inventory data for the entire State have been compiled. It is expected, however, that any such changes will be minor.

\section{General}

Michigan's Southern Lower Peninsula Unit (fig. 1 ) is comprised of 35 counties and is the most heavily populated unit in the State. The region is bounded by Lake Michigan, Lake Huron, and Lake Erie, which provide international access for a multitude of products from this region, including a wide array of forest based products.

Agriculture and urban/industrial development dominate land-use and economic activity in southern Michigan. However, forest land represented 21 percent of all land in the Survey Unit in 1993, and provided economic. ecological, scenic, and recreational diversity for the region.

As with most forest land in this region of the United States, the forests in the Southern Lower Peninsula were subjected to intensive harvesting during early European settlement. In addition, widespread slash burning and wildfire, unleashed because of the lack of adequate fire control, contributed to the understocking and poor condition of most of the forest lands by the turn of the 19th century. However, that trend reversed during the early 1900's as regrowth of the forest resource began, in conjunction with organized wildfire control and active forest management. From 1935 through 1955, most of the regenerated forest reached sapling to poletimber sizes (Chase and Pfeifer 1970). These trees have continued to grow into larger diameter classes. Now, the current forest resource is well stocked with a wide range of diameter classes. The following are a few major highlights from the 1993 inventory of the Southern Lower Peninsula Survey Unit. 


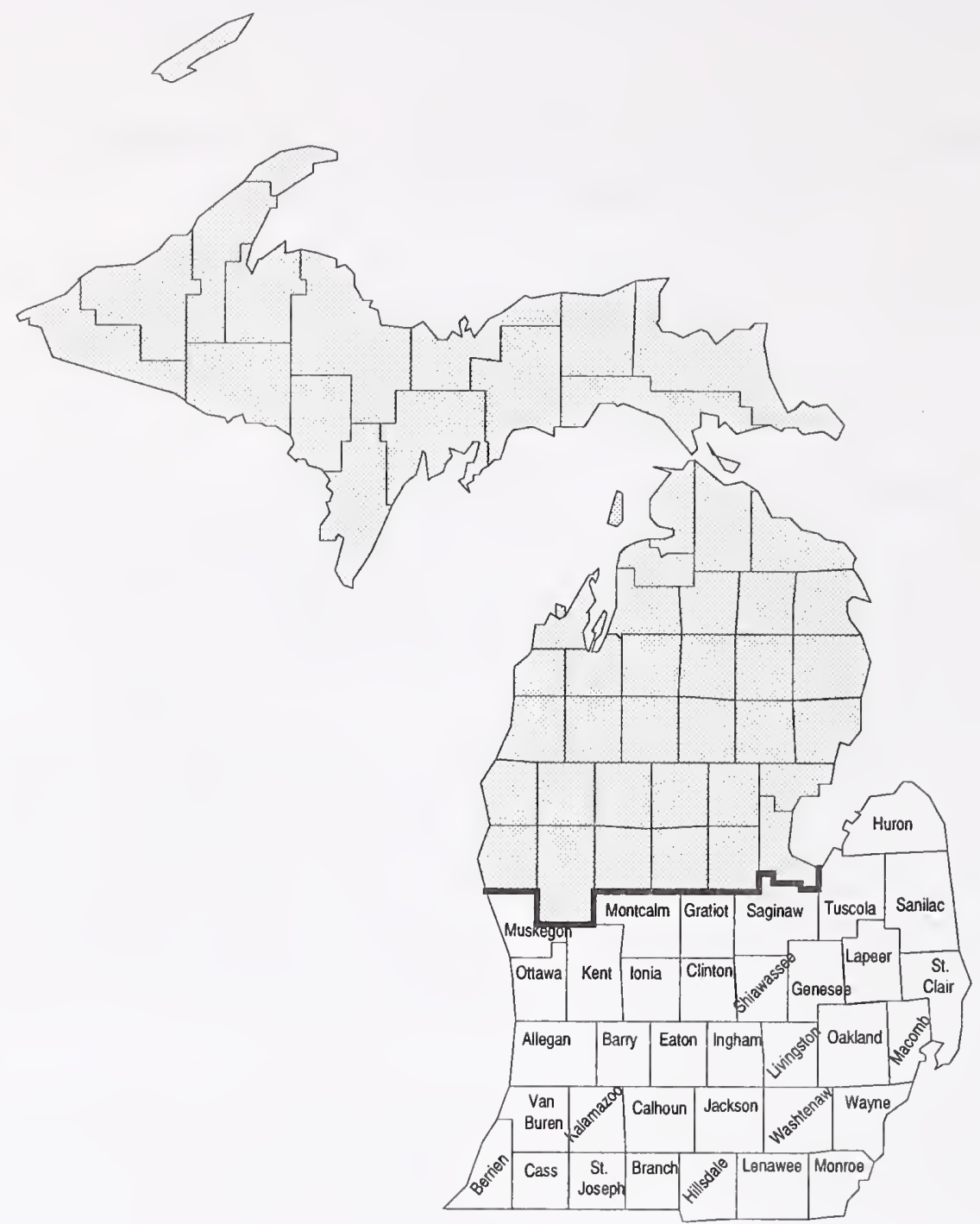

Figure 1.-Southern Lower Peninsula Survey Unit, 1993.

\section{Area}

- Forest land accounted for more than $3,053,700$ acres in 1993,21 percent of the total land area (excluding water). Of this total, timberland occupied $3,000,700$ acres, and reserved forest land occupied 53,000 acres.

- Timberland increased in area by 20 percent, adding more than 524,000 acres from 1980 to 1993 . This represents an average increase of 40,000 acres each year. Most of the increase came from abandoned cropland and pasture on which trees became established through either planting or natural succession between 1980 and 1993.
- In 1993, the 3 million acres of timberland represented the highest level of total timberland area since forest inventories began in this Survey Unit (fig. 2). This increase occurred as new forest stands were established on land previously used in other ways, while existing stands continued to grow and move into the larger stand-size classes.

- More than 738,000 acres of land were classed as nonforest with trees in 1993, an increase of more than 570,000 acres since 1980. These lands have the potential to become forest land if the existing trees are allowed to grow, and if additional tree invasion occurs. 


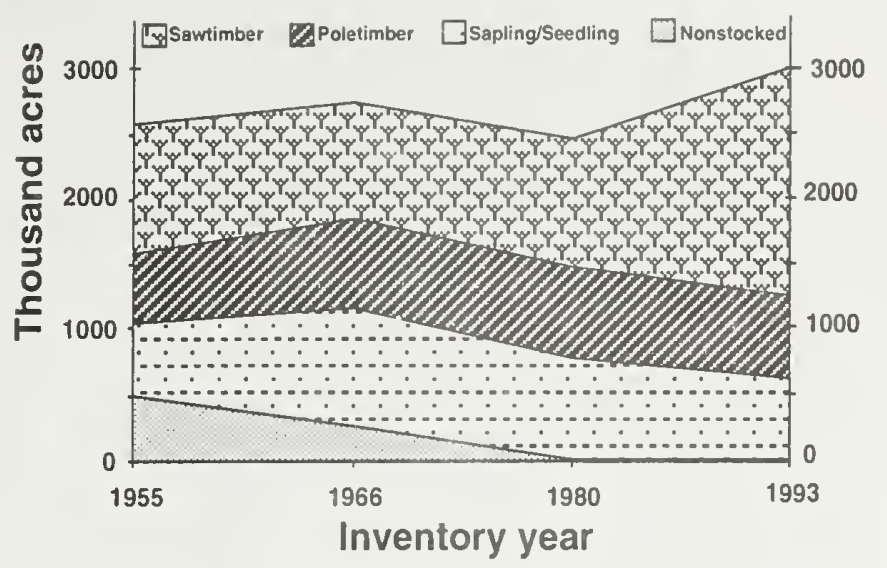

Figure 2.-Timberland area by stand-size class from forest inventories of the Southern Lower Peninsula in 1955, 1966, 1980, and 1993.

- Area of wooded strips decreased between inventories. In 1980, there were more than 183,000 acres in wooded strips compared to 110,000 acres in 1993. About half of this decline was due to reclassification of some wooded strips that had expanded to more than 120 feet in width, putting them into the forest land category. The other half of the decline was due to the removal of other wooded strips. Where the decline occurred due to physical removal, it represents an important loss because wooded strips provide: water quality improvement by filtering sediments and other pollutants; shading for rivers and streams, which helps to lower the water temperature and improves fish habitat; wildlife habitat and escape cover; soil erosion protection; and aesthetics.

- As in 1980, the group that owned the largest area of timberland was the farmer/ miscellaneous private individuals group, with 2.4 million acres in 1993. Miscellaneous private corporations were the second largest owner group in 1993, accounting for almost 260 thousand acres. In 1993, about 89 percent of all timberland in the Unit was privately owned (fig. 3).

- The largest public timberland owner in 1993 was the State, which added substantially to its timberland ownership between inventories, increasing from 150,000 acres in 1980 to 238,000 acres in 1993. In 1993, the State of Michigan owned timberland in 22 of the 35 counties in this Survey Unit.

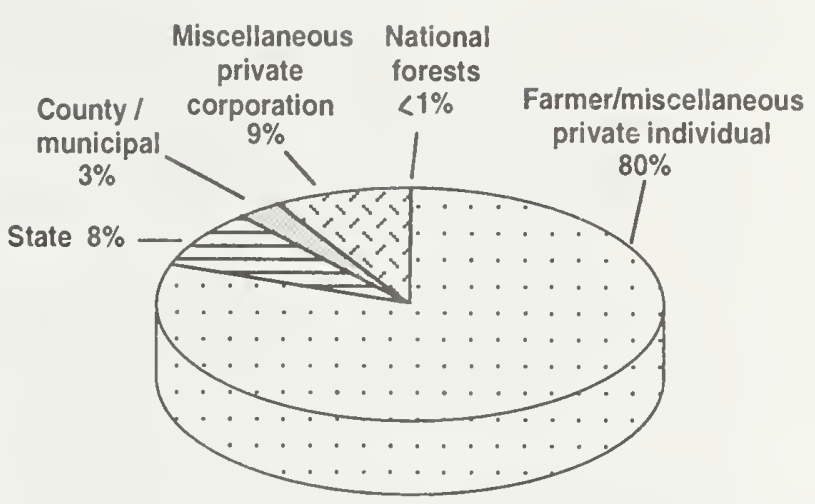

Figure 3.-Ownership of timberland in the Southern Lower Peninsula in 1993.

- Maple-birch was the dominant forest type with more than 1.3 million acres in 1993. The oak-hickory and elm-ash-soft maple forest types were second and third, respectively. These three forest types accounted for 90 percent of the total area of timberland in 1993 (fig. 4).

- All hardwood forest types except aspen increased in area of timberland between 1980 and 1993 (fig. 4). Aspen declined by one-third in timberland area, falling from 181 thousand acres in 1980 to 121 thousand acres by 1993. The loss of aspen was probably due to succession as the intolerant shorter lived aspen succumbed to old age and was replaced by longer lived, shade tolerant hardwoods that had been present in the understory of undisturbed stands.

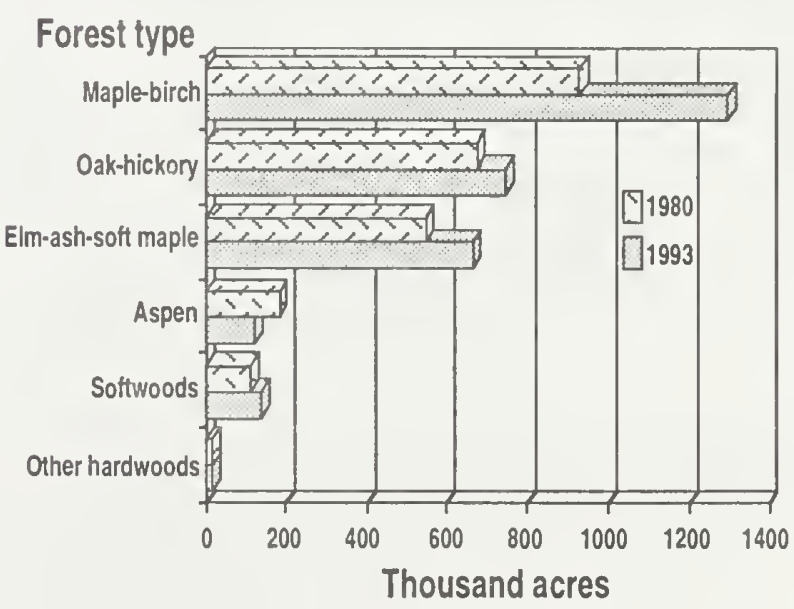

Figure 4.-Area of timberland by forest types, Southern Lower Peninsula, 1993. 
- Area of nonstocked timberland has steadily decreased from a high of almost 20 percent of all timberland in 1955 to less than 1 percent in 1993 (fig. 2). From 1955 through 1993, the area of poletimber-sized stands remained relatively stable. The major gains in area of timberland by stand-size class since 1955 have occurred with the sawtimber-size class. By 1993, sawtimber stands accounted for 58 percent of all timberland. Poletimber and sapling/ seedling stands represented 22 percent and 20 percent, respectively, of all timberland.

\section{Volume}

- Total volume of growing stock increased from 2.6 billion cubic feet in 1980 to 4.2 billion in 1993, an increase of more than 60 percent between inventories. Growing stock increased an average of more than 126 million cubic feet each year.

- The hard hardwood species group accounted for 50 percent of the total growingstock volume in 1993, with more than 2.1 billion cubic feet. Soft hardwoods contributed an additional 1.8 billion cubic feet, 44 percent of the total growing-stock volume in 1993 (fig. 5).

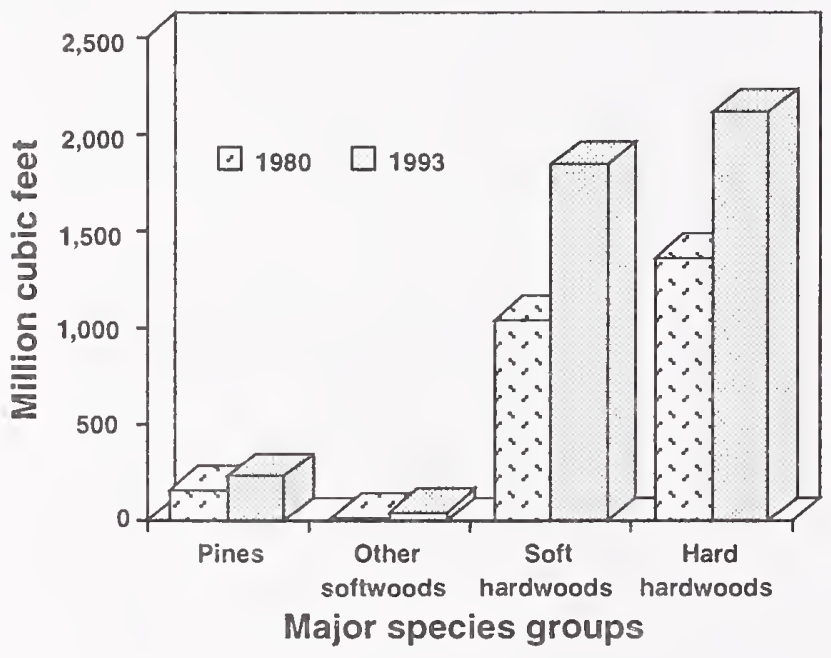

Figure 5.-Growing-stock volume for major species groups in the Southern Lower Peninsula, 1980 and 1993.
- Most forest types increased in growingstock volume between 1980 and 1993 (fig. $6)$. The greatest increase occuried in the maple-birch forest type, as more than 800 million cubic feet were added during the 13 years between inventories.

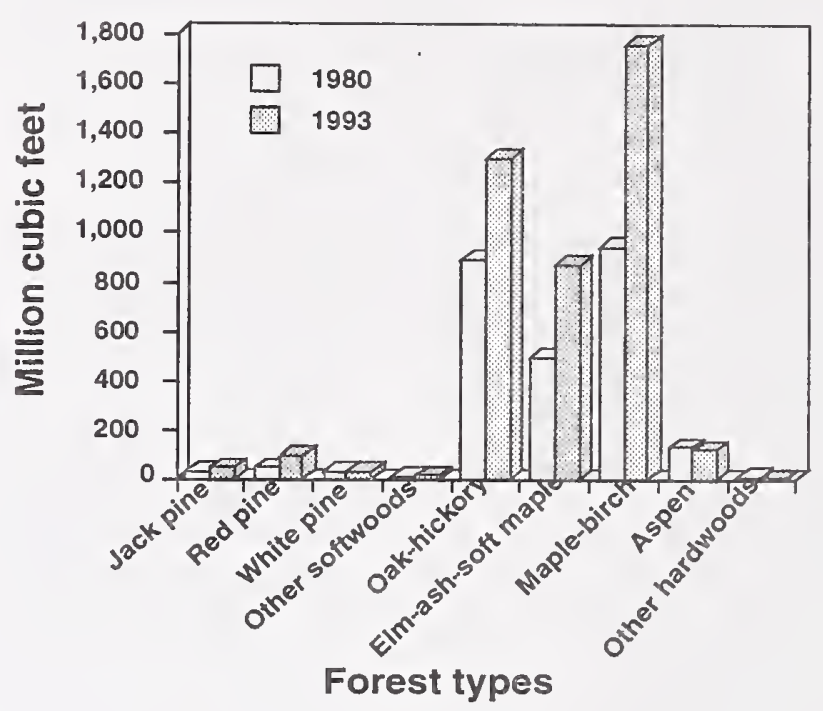

Figure 6.-Growing-stock volume by forest type, Southern Lower Peninsula, 1980 and 1993.

- Timberland averaged more than 1,400 cubic feet of growing-stock volume per acre in 1993, compared to about 1,000 cubic feet per acre in 1980. Timberland is becoming better stocked with larger trees as the forests that regenerated in the early 1900's mature.

- Growing-stock volume accounted for 90 percent of the total volume of all live trees in 1993. The remaining 10 percent consisted of short-log, rough, and rotten trees that were classified as live but did not meet the standards for growing stock.

- The soft maple species group represented the largest volume of sawtimber with more than 2.3 billion board feet in 1993. Select red oak and select white oak species groups were second and third in total sawtimber volume, respectively, with both having about 1.7 billion board feet in 1993 . 


\section{Growth}

- Total gross growing-stock average annual growth (net growth plus mortality) between 1980 and 1992 was more than 169 million cubic feet in the Southern Lower Peninsula. In comparison, the average annual net growth (total gross growth less mortality) for growing stock was 148 million cubic feet.

- From 1980 through 1992, average annual net growth for all species on timberland was nearly 50 cubic feet of growing stock per acre. This average annual net growth rate represented 3.5 percent of the growing-stock inventory in the Southern Lower Peninsula.

- Current (1992) net growth for all species on timberland was nearly 157 million cubic feet, 9 million cubic feet more than the 13-year average annual net growth between inventories.

- Soft hardwoods led all major species groups with an average of more than 70 million cubic feet of growing-stock growth per year from 1980 through 1992 (fig. 7). In addition, hard hardwoods contributed more than 65 million cubic feet of growingstock growth annually between inventories.

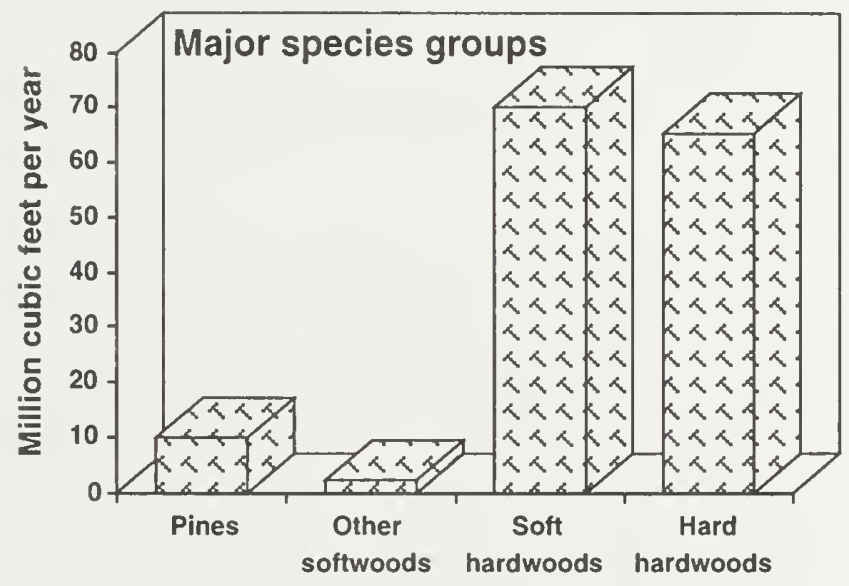

Figure 7.-Average annual net growth of growing stock for major species groups in the Southern Lower Peninsula, 1980-1992.
- Within hardwood species groups, soft maple, select red oak, and white/green ash all averaged more than 15 million cubic feet of growing stock net growth per year between 1980 and 1992 (fig. 8).

- Within softwood species groups, red pine and white pine averaged more than 4 million cubic feet of growing-stock net growth per year between 1980 and 1992 (fig. 9).

- Soft maple led all hardwood species groups in average sawtimber growth, with almost 90 million board feet per year from 1980 through 1992. White and green ash, select red oaks, and select white oaks averaged more than 40 million board feet of sawtimber growth each year.

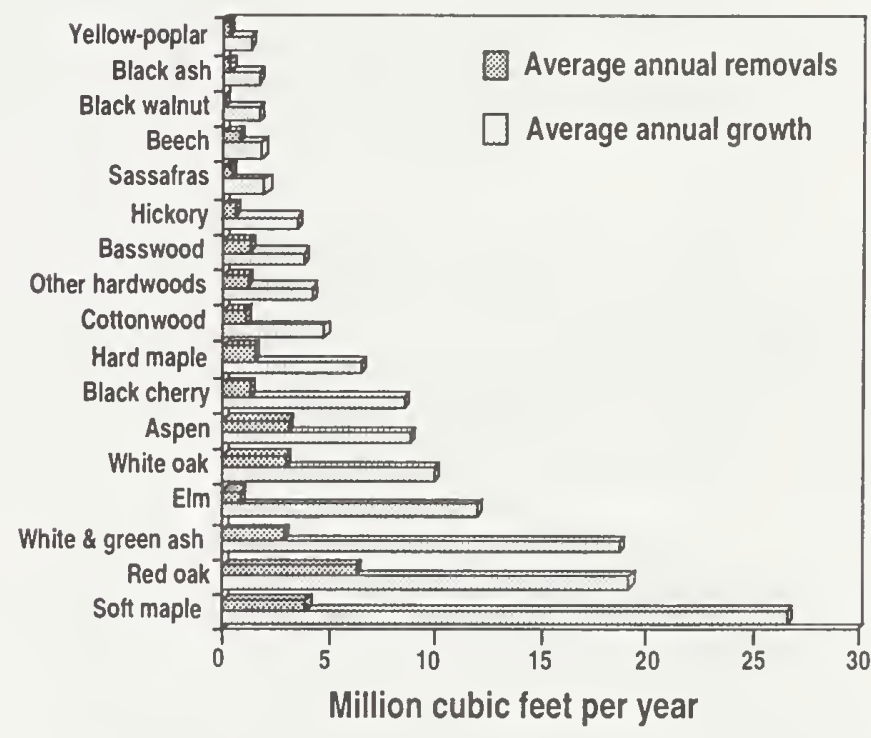

Figure 8.-Comparison of average annual hardwood growing-stock growth with removals, by species group, Southern Lower Peninsula, 1980-1992.

- Softwood sawtimber averaged more than 59 million board feet of net growth per year between 1980 and 1992 . White pine, with more than 23 million board feet, and red pine, with nearly 20 million board feet, accounted for 73 percent of all softwood sawtimber growth between inventories. 


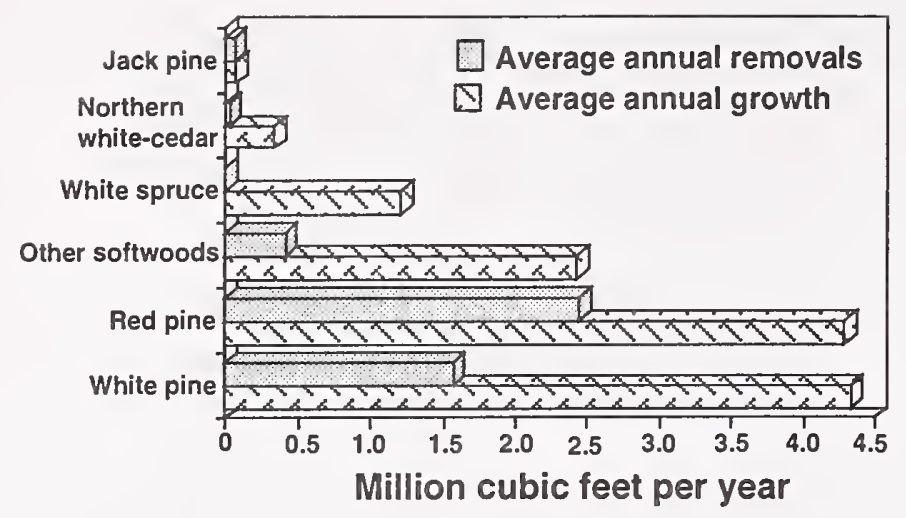

Figure 9.-Comparison of softwood growingstock growth with removals, by species group in the Southern Lower Peninsula, 1980-1992.

\section{Removals}

- Annual growing-stock removals averaged less than 1 percent of total growing-stock volume and about 22 percent of the annual net growth volume between 1980 and 1992. During this period, removals averaged more than 33 million cubic feet per year.

- $\quad$ Current growing-stock removals were 20.3 million cubic feet in 1990 (1990 is the most recent mill survey for the Southern Lower Peninsula), which was about 12.8 million cubic feet less than the 13-year average between inventories.

- Average annual removals of hardwood growing stock represented 21 percent of hardwood average annual growth from 1980 through 1992 (fig. 8).

- Removals of hardwood growing-stock occurred primarily in the select and other red oaks, soft maple, select white oak, white and green ash, and aspen species groups. These species groups accounted for 67 percent of all hardwood growingstock removals each year from 1980 through 1992.
- Average annual removals of softwood growing stock represented 36 percent of softwood average annual growth from 1980 through 1992 (fig. 9). Removals of softwood growing stock were primarily in red pine and white pine.

- Average annual hardwood sawtimber removals were 21 percent of average annual sawtimber growth from 1980 through 1992. Most sawtimber removals occurred in the select red oak, soft maple, and select white oak species groups, with more than 10 million board feet removed annually from each of these species groups.

\section{Mortality}

- Annually, growing-stock mortality averaged 21.5 million cubic feet between inventories. Sawtimber mortality averaged 45.8 million board feet during this time period. These totals represent annual losses of less than 1 percent of both volumes.

- Current growing-stock mortality (1992) was 20.6 million cubic feet and current sawtimber mortality (1992) was 46.9 million board feet in the Southern Lower Peninsula. Both current mortality levels were nearly identical to the 13-year average.

- Dutch elm disease continued to ravage the elm species group. From 1980 through 1992, elm represented almost 20 percent of all growing-stock mortality, but accounted for less than 5 percent of the total volume.

- Soft maple, elm, red oak, aspen, and white and green ash species groups recorded more than 60 percent of all sawtimber mortality from 1980 through 1993. Mortality of these species groups averaged more than 3 million board feet of sawtimber each year. 


\section{APPENDIX}

\section{ACCURACY OF THE SURVEY}

Forest Inventory and Analysis (FIA) information is based on a sampling procedure designed to provide reliable statistics at the State and Survey Unit levels. Consequently, the reported figures are estimates only. A measure of reliability of these figures is given by sampling errors. The level of sampling error used by FIA means the chances are two out of three that if a 100-percent inventory had been taken, using the same methods, the results would have been within the limits indicated.

For example, the estimated growing-stock volume in the Southern Lower Peninsula Unit in Michigan in 1993, 4,238.5 thousand cubic feet, has a sampling error of \pm 2.19 percent $( \pm$ 92.8 thousand cubic feet). Based on this sampling error, growing-stock volume from a 100-percent inventory would be expected to fall between 4,145.7 and 4,331.3 thousand cubic feet $(4,238.5 \pm 92.8)$, there being a one in three chance that this is not the case. The following tabulation shows the sampling errors for Michigan's Southern Lower Peninsula Forest Inventory:

\begin{tabular}{|c|c|c|}
\hline Item & it totals Sar & npling error \\
\hline Growing stock & n cubic feet) & (Percent) \\
\hline Volume (1993) & $4,238.5$ & 2.19 \\
\hline Average annual & & \\
\hline growth (1980-1992) & 148.1 & 2.40 \\
\hline Average annual & & \\
\hline removals (1980-1992) & 33.4 & 11.85 \\
\hline Sawtimber & n board feet) & \\
\hline Volume (1993) & $13,044.5$ & 2.89 \\
\hline Average annual & & \\
\hline growth (1980-1992) & 516.4 & 2.90 \\
\hline Average annual & & \\
\hline removals (1980-1992) & 116.0 & 13.06 \\
\hline Timberland & isand acres) & \\
\hline area (1993) & $3,000.7$ & 1.29 \\
\hline
\end{tabular}

As survey data are broken down into sections smaller than Survey Unit totals, the sampling error increases. For example, the sampling error for timberland area in a particular county is higher than that for total timberland area in the Unit. This tabulation shows the sampling errors for Unit totals. To estimate sampling error for data smaller than Unit totals, use the following formula:

$$
E=\frac{(S E) \quad \sqrt{\text { (Unit total area or volume) }}}{\sqrt{\text { (Volume or area smaller than Unit total) }}}
$$

where:

$\mathrm{E}=$ sampling error in percent

$\mathrm{SE}=$ Unit total error for area or volume

For example, to compute the error on the area of timberland in the maple-birch type for the Unit:

1. Total area of timberland in the maplebirch forest type from table $3=$ 1,300,900 acres;

2. Total area of all timberland in the Unit from table $3=3,000,700$ acres;

3. Unit total error for timberland area from the above tabulation $=1.29$ percent .

Using the above formula:

$$
E=\frac{(1.29) \sqrt{(3,000,700)}}{\sqrt{(1,300,900)}}= \pm 1.96 \text { percent }
$$

\section{County Data}

A standard FLA inventory is designed to provide sampling errors of no more than 3 percent per million acres of timberland. Thus, this Unit's 3,000.7 thousand acres of timberland required a sampling error of 1.73 percent to meet national FIA standards. Because the 35 counties in the Southern Lower Peninsula were inventoried at a single level of intensity, sampling errors will increase if data from this inventory effort are utilized below the unit level. Caution must be used accordingly. The sampling error within an individual county depends on county size and total area of timberland. 


\section{COMPARING THE FIFTH INVENTORY OF THE SOUTHERN LOWER PENINSULA WITH THE FOURTH INVENTORY}

A new volume estimation procedure has been developed for the Lake States since the last survey conducted in 1980. We used this procedure to compute the 1993 volumes and to re-compute the 1980 volume for growth calculations. Although the adjustment will differ by species, the re-computed 1980 volumes will generally be greater than those shown in the original 1980 report.

Past surveys used only growing-stock trees to determine stand-size class. Current survey procedures require that stand-size class be determined on the basis of all live trees. Therefore, direct comparisons of current inventory data to old inventory data by standsize class may be misleading.

The basic building block for estimating forest area and timber volume has been changed from the Survey Unit (as utilized during the 1980 inventory) to the county (current methodology). In the past, statistics were developed at the Unit level and prorated back to the county on the basis of photo-interpretation results. Direct development of county-level data helps users interested in more precise local data, but can make the outcome of comparisons with past estimates uncertain.

\section{SURVEY PROCEDURES}

The 1993 survey of Michigan's Southern Lower Peninsula used a growth model enhanced, two-phase sample design. Using this sampling scheme and associated estimators is similar to sampling with partial replacement, in that a set of randomly located plots is available for remeasurement and a random set of new plots is established and measured. A significant feature of the new design is stratification for disturbance on the old sample and use of a growth model to improve regression estimates made on old undisturbed forest plots (fig. 10). Detailed descriptions of the sampling and estimation procedures are presented by Hansen (1990). The growth model used was the Lake States Stand and Tree Evaluation and Modeling System (STEMS) (Belcher et al. 1982).

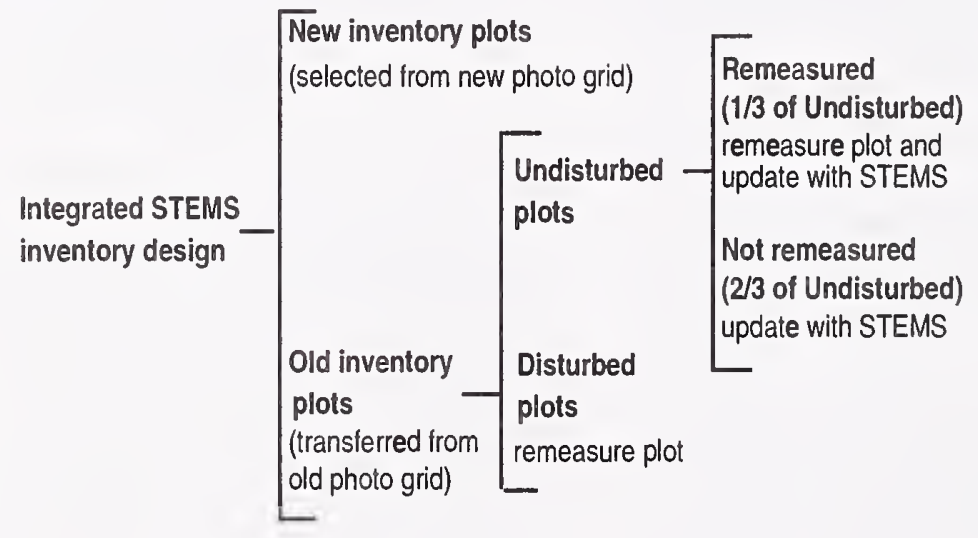

Figure 10.-Overview of the sample design for the Southern Lower Peninsula's 1993 survey. 


\section{Major Steps in the New Survey Design}

\section{Aerial photography (Phase 1)}

In this phase, two sets of random points were located on current aerial photographs. The first set was new photo plots, and the second set was relocated, old ground plot locations from the 1980 inventory. Locations of the plots used in the 1980 inventory were transferred to the new photographs. The photographs were then assembled into township mosaics, and a systematic grid of 121 one-acre photo plots (each plot representing approximately 190.4 acres) was overlaid on each township mosaic. Each photo plot was examined by aerial photogrammetrists and classified stereoscopically as to its land use. If trees were present, forest type and stand-size/ density classes were recorded. All of the 1980 ground plot locations were also examined for disturbance (logging, fire, catastrophic mortality, etc.). After this examination, all the old "disturbed" sample locations and one-third of the old "undisturbed" forested plots were sent to the field for survey crews to verify the photo classification and to take further measurements. All photo plot locations for the 1993 inventory were examined and classified as shown in the following tabulation.

$\begin{array}{lr}\text { Photo land class } & \text { Photo plots } \\ \text { Timberland } & 15,955 \\ \text { Reserved forest land } & 314 \\ \text { Other forest land } & 0 \\ \text { Questionable } & 552 \\ \text { Nonforest with trees } & 4,357 \\ \text { Nonforest without trees } & 55,822 \\ \text { Water } & 978 \\ \text { All classes } & 77,978\end{array}$

\section{Plot measurements (Phase 2)}

On plots classified as timberland, wooded pasture, or windbreak (at least 120 feet wide), a ground plot was established, remeasured, or modeled. Old plots sent to the field for remeasurement that could not be relocated were replaced with a new plot at the approximate location of the old one. Each ground plot consisted of a 10-point cluster covering 1 acre. At each point, trees 5.0 inches or more d.b.h. were sampled on a 37.5 basal area factor variable-radius plot, and trees less than 5.0 inches d.b.h. were sampled on a 1/300-acre fixed-radius plot. The measurement procedure for both the new and old sample locations was as follows:

\section{a. New inventory plots}

A random sample of the new photo plots was selected for field measurement. Ground plots were established, and measures of current classification such as land use, forest type, and ownership, as well as size and condition of all trees on the plot, were recorded. These locations were monumented for future remeasurement.

\section{b. Old inventory plots}

These plots were originally established, monumented, and measured as part of the 1980 field inventory. Procedures for these old plots were different from those for the new plots. Old plots were classed as "undisturbed" or "disturbed" in the aerial photo phase of the sampling process. All disturbed plots and a one-third sample of the undisturbed forested plots were remeasured to obtain estimates of current condition and changes since the last inventory. All trees measured on these plots in 1980 were remeasured or otherwise accounted for, and all new trees were identified and measured.

All sample plots that were forested at the time of the 1980 inventory and determined to be undisturbed until the 1993 inventory were projected to the current time (1993) using STEMS. This procedure gives projected estimates of current volume and growth for undisturbed plots. Comparison of the projected and observed values on the one-third sample of the undisturbed forest plots that were remeasured provided local calibration data to adjust the projected values of the undisturbed plots that were not remeasured. The adjustment procedure is a modified version of the method described by Smith (1983).

Undisturbed forested plots that were not remeasured played a crucial role in the new survey design. These plots, after careful comparison of past and current aerial photography, were determined to be undisturbed and had conditions that could be simulated by 
STEMS. The STEMS growth model was used to "grow" the old plot and tree data to produce an estimate of current data. Thus, these plots were treated as ground plots, even though they were never visited. The plot record for each modeled plot was sent to the field for verification of current ownership information.

All old plots classified as disturbed were sent to the field for remeasurement to assess and verify changes since the last inventory. Disturbance referred to any change on a plot that was detected on aerial photos and that the STEMS growth processor could not predict, such as catastrophic mortality, cutting, seedling stands, and/or land use change.

The estimation procedure for computing statistics from this sampling design was more complicated than the simple two-phase estimation procedure used in the past. In fact, this procedure yielded two independent samples, one coming from the new photo points and the other from the old photo points that were remeasured or modeled. The following tabulation summarizes the distribution of all ground plots for the new inventory design by type of plot:

\section{Area estimates}

Area estimates were made using two-phase estimation methods. In this type of estimation, a preliminary estimate of area by land use is made from the aerial photographs (Phase 1) and corrected by the plot measurements (Phase 2). A complete description of this estimation method is presented by Loetsch and Haller (1964). All area estimates were based on what existed as of January 1 , 1993, in the Southern Lower Peninsula of Michigan.

\section{Volume estimates}

Estimates of volume per acre were made from the trees measured or modeled on the 10-point plots. Estimates of volume per acre were multiplied by the area estimates to obtain estimates of total volume. Volume estimates were based on what existed as of January 1, 1993, in the Southern Lower Peninsula of Michigan. Net cubic foot volumes were based on a modification of the method presented by Hahn (1984) for use in the Lake States. For the Southern Lower Peninsula inventory, the merchantable height equation presented was used in conjunction with Hahn's board foot volume equation (adapted from Stone's equation-Hahn 1984) to estimate gross volume.

Ground land
use class
Timberland
Reserved forest land
Nonforest with trees
Nonforest without trees
Water
Total

\section{Old plots} updated remeasured

\begin{tabular}{rrrr}
506 & 233 & 165 & 904 \\
6 & 0 & 47 & 53 \\
137 & 64 & 58 & 259 \\
1,543 & 1,455 & 606 & 3,604 \\
40 & 33 & 43 & 116 \\
\hline 2,232 & 1,785 & 919 & 4,936
\end{tabular}


This estimate was then corrected by species for variation in bark and cull volume to yield an estimate of net volume (Hahn 1984).

The Forest Service reports all board foot volume in International 1/4-inch rule. In Michigan, the Scribner log rule is commonly used. Scribner log rule conversion factors were derived from full tree measurements taken throughout the Lake States (Michigan, Wisconsin, and Minnesota) and an equation developed by Wiant and Castenaeda (1977). Factors, or multipliers, that can be used to convert board foot International volumes to the Scribner rule are shown in the following tabulation:

$\begin{array}{crc}\begin{array}{c}\text { D.b.h. } \\ \text { (inches) }\end{array} & \begin{array}{c}\text { Scribner rule conversion factor } \\ \text { Softwoods }\end{array} & \begin{array}{c}\text { Hardwoods } \\ \text { 9.0-10.9 }\end{array} \\ 11.0-12.9 & 0.7830 & - \\ 13.0-14.9 & .8287 & .8317 \\ 15.0-16.9 & .8577 & .8611 \\ 17.0-18.9 & .8784 & .8827 \\ 19.0-20.9 & .8945 & .8999 \\ 21.0-22.9 & .9079 & .9132 \\ 23.0-24.9 & .9168 & .9239 \\ 25.0-26.9 & .9240 & .9325 \\ 27.0-28.9 & .9299 & .9396 \\ 29.0+ & .9321 & .9454 \\ & .9357 & .9544\end{array}$

\section{Growth and mortality estimates}

On remeasured plots, estimates of growth and mortality per acre come from the remeasured diameters of trees and from observation of trees that died between inventories. Growth reported as the average net annual growth between the two inventories (1980 and 1992) was computed from data on remeasurement plots and modeled plots using methods presented by VanDeusen et al. (1986). Mortality was also reported as average annual for the remeasurement period. On new plots, where trees were not remeasured, estimates of growth and mortality were obtained by using STEMS to project the growth and mortality of trees for 1 year. Growth and mortality estimates for old undisturbed plots that were updated were derived in the same manner as remeasured plots. The STEMS growth model was adjusted to meet local conditions, using data from the undisturbed remeasurement plots. As with volume, total growth and mortality estimates were obtained by multiplying the per acre estimates by area estimates.
Current annual growth for 1992 was computed by using the adjusted STEMS model to grow all current inventory plots for 1 year. All growth and mortality estimates were based on growth and mortality through December 31, 1992, in the Southern Lower Peninsula of Michigan.

\section{Average annual removals estimates}

Average annual growing-stock and sawtimber removals (1980 to 1992) were estimated only from the remeasured plots; new plots were not used to estimate removals. These estimates are obtained from trees measured in the last survey and cut or otherwise removed from the timberland base. All removal estimates were based on removals through December 31 , 1992, in the Southern Lower Peninsula of Michigan. Because remeasurement plots make up about one-half of the total ground plots, average annual removals estimates have greater sampling errors than volume and growth estimates.

\section{Tree and Log Grades}

On approximately one-third of the sample plots in Michigan's Southern Lower Peninsula, all sawtimber sample trees were graded for quality and assigned either a tree grade (hardwoods) or a log grade (softwoods). Tree and log grades were based on the evaluation of external characteristics as indicators of quality. The volume yield by grade for this sample was used to distribute the volume of the ungraded sample trees by species group. Hardwood sawtimber trees were graded according to "Hardwood tree grades for factory lumber" (Hanks 1976). The best 12 -foot section of the lowest 16-foot hardwood log was used for grading. Hardwood sawtimber trees that did not meet minimum tree grade specifications for grades 1 through 3 were assigned grade 4 according to Forest Service standard specifications for hardwood construction logs described in "A guide to hardwood log grading" (Rast et al. 1973). Red pine and jack pine sawtimber trees were graded based on specifications described in "Forest Service log grades for southern pines" (Campbell 1964). White pine and other softwood sawtimber trees were graded according to specifications described in "Sawlog grades for eastern white pine (Ostrander and Brisbin 1971). For all softwoods, the first merchantable 16-foot log, or shorter lengths down to 12 feet, was used for grading. 
Hardwood Tree Grades for Factory Lumbera

\begin{tabular}{|c|c|c|c|}
\hline Grade factor & $\begin{array}{c}\text { Tree grade } \\
1 \\
\end{array}$ & $\begin{array}{c}\text { Tree grade } \\
2 \\
\end{array}$ & $\begin{array}{c}\text { Tree grade } \\
3\end{array}$ \\
\hline Length of grading zone (feet) & Butt 16 & Butt 16 & Butt 16 \\
\hline Length of grading section ${ }^{b}$ (feet) & Best 12 & Best 12 & Best 12 \\
\hline D.b.h., minimum (inches) & $16^{c}$ & 13 & 11 \\
\hline $\begin{array}{l}\text { Diameter, minimum inside bark at top of } \\
\text { grading section (inches) }\end{array}$ & $13^{c} 16 \quad 20$ & $11^{d} 12$ & 8 \\
\hline $\begin{array}{l}\text { Clear cuttings (on the three best faces) } \\
\text { Length, minimum (feet) } \\
\text { Number on face (maximum) } \\
\text { Yield in face length (minimum) }\end{array}$ & $\begin{array}{ccc}7 & 5 & 3 \\
2 & \\
& 5 / 6\end{array}$ & $\begin{array}{l}3 \\
2 \\
4 / 6\end{array}$ & $\begin{array}{c}2 \\
(f) \\
3 / 6\end{array}$ \\
\hline $\begin{array}{l}\text { Cull deduction (including crook and } \\
\text { sweep, but excluding shake) } \\
\text { maximum within grading section } \\
\text { (percent) }\end{array}$ & 9 & $g^{g}$ & 50 \\
\hline
\end{tabular}

a (Hanks 1976).

$b$ Whenever a 14- or 16-foot section of the butt 16-foot log is better than the best 12-foot section, the grade of the longer section will become the grade of the tree. This longer section, when used, is the basis for determining the grading factors.

c In basswood and ash, diameter inside bark (d.i.b.) at top of grading section must be 12 inches and d.b.h. must be 15 inches.

$d$ Grade 2 trees can be 10 inches d.i.b. at top of grading section if otherwise meeting surface requirements for small grade 1's.

e A clear cutting is a portion of a face free of defects, extending the width of the face. A face is one-fourth of the surface of the grading section as divided lengthwise.

$f$ Unlimited.

9 Fifteen percent crook and sweep or 40 percent total cull deduction are permitted in grade 2 , if size and surface of grading section qualify as grade 1. If rot shortens the required clear cuttings to the extent of dropping the butt log to grade 2, do not drop the tree's grade to 3 unless the cull deduction for rot is greater than 40 percent. 
Forest Service Standard Specifications for Hardwood Construction Logs (Tie and Timber logs) ${ }^{a, b}$

\begin{tabular}{|c|l|}
\hline Position in tree & Butts and uppers \\
\hline Minimum diameter, small end & 8 inches + \\
\hline Minimum length without trim & 8 feet + \\
\hline Clear cuttings & No requirements \\
\hline Sweep allowance & $\begin{array}{l}\text { One-fourth small end d.i.b. for each } 8 \text { feet of } \\
\text { length. One-half d.i.b. for logs 16 feet long. }\end{array}$ \\
\hline Sound surface defects: & $\begin{array}{l}\text { Any number, if no knot has an average } \\
\text { diameter above the callus in excess of one- } \\
\text { third of the log diameter at point of } \\
\text { occurrence. }\end{array}$ \\
\hline Wingle knots & $\begin{array}{l}\text { Any number, if the sum of knot diameters } \\
\text { above the callus does not exceed one-third } \\
\text { of the log diameter at point of occurrence. }\end{array}$ \\
\hline Interior & $\begin{array}{l}\text { Same requirements as for sound defects if } \\
\text { they extend into included timber. No limit if } \\
\text { they do not. }\end{array}$ \\
\hline Surface & $\begin{array}{l}\text { None permitted except one shake not more } \\
\text { than one-third the width of contained tie or } \\
\text { timber, and one split, not over } 5 \text { inches. }\end{array}$ \\
\hline Unsound defects: & \\
\hline Whots
\end{tabular}

a These specifications are minimum for the class. If, from a group of logs, factory logs are selected first, thus leaving only nonfactory logs from which to select construction logs, then the quality range of the construction logs so selected is limited, and the class may be considered a grade. If selection for construction logs is given first priority, it may be necessary to subdivide the class into grades.

b (Rast et al. 1973). 
Eastern White Pine Saw-log Grade Specifications ${ }^{a}$

\begin{tabular}{|c|c|c|c|c|}
\hline Grading factor & Log grade 1 & Log grade 2 & Log grade 3 & Log grade 4 \\
\hline $\begin{array}{l}\text { 1. Minimum scaling } \\
\text { diameter (inches) }\end{array}$ & $14^{b}$ & 6 & 6 & 6 \\
\hline $\begin{array}{l}\text { 2. Minimum log length } \\
\text { (feet) }\end{array}$ & $10^{c}$ & 8 & 8 & 8 \\
\hline $\begin{array}{l}\text { 3. Maximum weevil } \\
\text { injury (number) }\end{array}$ & None & None & 2 injuries $d$ & No limit \\
\hline $\begin{array}{l}\text { 4. Minimum face } \\
\text { requirements }\end{array}$ & $\begin{array}{l}\text { Two full length } \\
\text { or four } 50 \% \text { e } \\
\text { length good } \\
\text { faces (in } \\
\text { addition, log } \\
\text { knots on } \\
\text { balance of } \\
\text { faces shall not } \\
\text { exceed size } \\
\text { limit of grade } \\
2 \text { logs). }\end{array}$ & $\begin{array}{l}\text { NO GOOD FACE } \\
\text { Maximum diame } \\
\text { three be } \\
\text { SOUND R } \\
\text { not to exceed 1/6 } \\
\text { scaling diameter } \\
\text { and } 3^{\prime \prime} \text { maximum } \\
\text { pVERGROWN/DEA } \\
\text { not to exceed } \\
1 / 12 \text { scaling } \\
\text { diameter and } \\
11 / 2 " \text { max. }\end{array}$ & $\begin{array}{l}\text { S REQUIRED } \\
\text { ter of log knots on } \\
\text { est faces: } \\
\text { ED KNOTS } \\
\text { not to exceed } 1 / 3 \\
\text { scaling diameter } \\
\text { and } 5^{\prime \prime} \text { maximum } \\
\text { D/BLACK KNOTS } \\
\text { not to exceed } \\
1 / 6 \text { scaling } \\
\text { diameter and } \\
21 / 2^{\prime \prime} \text { max. }\end{array}$ & $\begin{array}{l}\text { Includes all logs } \\
\text { not qualifying for } \\
\text { No. } 3 \text { or better } \\
\text { and have at } \\
\text { least } 1 / 3 \text { of their } \\
\text { gross volume in } \\
\text { sound wood } \\
\text { suitable for } \\
\text { manufacture into } \\
\text { standard lumber }\end{array}$ \\
\hline $\begin{array}{l}\text { 5. Maximum sweep or } \\
\operatorname{crook}(\%)\end{array}$ & 20 & 30 & 40 & $662 / 3$ \\
\hline $\begin{array}{l}\text { 6. Maximum total } \\
\text { scaling deduction } \\
(\%)\end{array}$ & 50 & 50 & 50 & $662 / 3$ \\
\hline
\end{tabular}

AFTER THE TENTATIVE LOG GRADE IS ESTABLISHED FROM FACE EXAMINATION, THE LOG WILL BE REDUCED IN GRADE WHENEVER THE FOLLOWING DEFECTS ARE EVIDENT

7. Conks, punk knots, and pine borer damage on bark surface $f$.

Degrade one grade if present on one face.

Degrade two grades if present on two faces.

Degrade three grades if present on three or more faces.

8. Log end defects: red rot, ring shake, heavy stain, and pine borer damage outside the heart center of $\log e$. Consider log as having a total of 8 quarters ( 4 on each end) and degrade as indicated.

Degrade one grade if present in 2 quarters of log ends.

Degrade two grades if present in 3 or 4 quarters of log ends.

Degrade three grades if present in 5 or more quarters of log ends.

a. $\quad$ (Ostrander and Brisbin 1971)

b. $\quad 12$ - and 13-inch logs with four full-length good faces are acceptable.

c. $\quad 8$-foot logs with four full-length good faces are acceptable.

d. $\quad 8$-foot Number 3 logs limited to one weevil injury.

e. Minimum $50 \%$ length good face must be at least 6 feet.

f. Factors 7 and 8 are not cumulative (total degrade based on more serious of the two). No $\log$ is to be degraded below grade 4 if net scale is at least one-third of gross scale. 


\section{Grade 1}

1. Logs must be 16 inches d.i.b. or larger, 10 feet in length or longer, and with deduction for defect, not over 30 percent of gross scale.

2. Logs must be at least 75 percent clear on each of three faces.

3. All knots outside clear cuttings must be sound and not more than 2-1/2 inches in size.

\section{Grade 2}

1. Logs must be 12 inches d.i.b. or larger, 10 feet in length or longer, and with a net scale after deduction for defect of at least 50 percent of the gross contents of the log.

2. Logs must be at least 50 percent clear on each of three faces or 75 percent clear on two faces.

\section{Grade 3}

1. Logs must be 6 inches d.i.b. or larger, 8 feet in length or longer, and with a net scale after deduction for defect of at least 50 percent of the gross contents of the log.

Note: Diameters are d.i.b. at small end of grading section, and percent clear refers to percent clear in one continuous section.

\section{METRIC EGUIVALENTS OF UNITS USED IN THIS REPORT}

1 acre $=4,046.86$ square meters or 0.405 hectare.

1,000 acres $=405$ hectares.

1 cubic foot $=0.0283$ cubic meter .

1 foot $=30.48$ centimeters or 0.3048 meter.

1 inch $=25.4$ millimeters, 2.54 centimeters, or 0.0254 meter.

1 pound $=0.454$ kilogram .

1 ton $=0.907$ metric ton .

\section{TREE SPECIES GROUPS IN MICHIGAN'S SOUTHERN LOWER PENINSULA}

Species names are based on Little, 1981.

\section{SOFTWOODS}

Balsam fir Abies balsamea

Eastern redcedar Juniperus virginiana

Tamarack Larix laricina

White spruce Picea glauca

Black spruce Picea mariana

Jack pine Pinus banksiana

Red pine Pinus resinosa

Eastern white pine Pinus strobus

Northern white-cedar Eastern hemlock

\section{HARDWOODS}

Hard maple ${ }^{1}$

Sugar maple

Soft maple ${ }^{2}$

Red maple Acer rubrum

Silver maple Tsuga canadensis
Birch

Yellow birch ${ }^{1}$ Betula alleghaniensis River birch ${ }^{2}$ Betula nigra

Paper birch ${ }^{2}$ Betula papyrifera Bitternut hickory ${ }^{1}$............... Carya cordiformis Hackberry ........................ Celtis occidentalis Persimmon ..................... Diospyros virginiana American beech .................. Fagus grandifolia Ash

White $\operatorname{ash}^{1}$.................. Fraxinus americana Black ash ${ }^{2}$......................... Fraxinus nigra Green ash ${ }^{1}$............. Fraxinus pennsylvanica Butternut ${ }^{2}$.........................Juglans cinerea Black walnut ${ }^{1}$.........................Juglans nigra White poplar ............................Populus alba Balsam poplar ................ Populus balsamifera Cottonwood .........................Populus deltoides Bigtooth aspen ${ }^{2}$........... Populus grandidentata Quaking aspen ${ }^{2}$...............Populus tremuloides Black cherry ..........................Prunus serotina Select white oak ${ }^{1}$

White oak Quercus alba Swamp white oak................. Guercus bicolor Bur oak Quercus macrocarpa

Select red oak ${ }^{1}$

Northern red oak Other red oak ${ }^{1}$

Northern pin oak

Pin oak

American basswood Quercus rubra Quercus ellipsoidalis ...Quercus palustris

\footnotetext{
${ }^{1}$ This species or species group is considered a hard hardwood, with an average specific gravity greater than or equal to 0.50 .

${ }^{2}$ This species or species group is considered a soft hardwood, with an average specific gravity of less than 0.50 .
} 
Elm

Winged elm ${ }^{2}$ Ulmus alata

American elm ${ }^{2}$ Ulmus americana Slippery elm ${ }^{2}$ Ulmus rubra

Rock elm ${ }^{1}$ Ulmus thomasii

Other hardwoods

Boxelder $^{2}$ Acer negundo

Ohio Buckeye ${ }^{2}$ Aesculus glabra

Sweet birch ${ }^{2}$ Betula lenta

Northern catalpa ${ }^{2}$ Catalpa speciosa

Noncommercial species

Striped maple ................Acer pennsylvanicum Mountain maple Acer spicatum American hornbeam ....... Carpinus caroliniana Hawthorn ........................... Crataegus spp. Apple Malus spp.

Eastern hophornbeam ......... Ostrya virginiana Canada plum ........................... Prunus nigra Pin cherry ...................... Prunus pensylvanica Wild plum Prunus spp. Chokecherry ......................Prunus virginiana Peachleaf willow ............... Salix amygdaloides Black willow ............................... Salix nigra Willow spp. ............................... Salix spp.

\section{DEFINITION OF TERMS}

\section{Average annual removals from growing} stock.-The average net growing-stock volume in growing-stock trees removed annually for forest products (including roundwood products and logging residues) and for other uses (see Other removals). Average annual removals of growing stock are reported for a period of several years (1980 through 1992 in this report) and are based on information obtained from remeasure-ment plots (see Survey Procedures in Appendix).

\section{Average annual removals from sawtimber.-}

The average net board foot sawtimber volume of live sawtimber trees removed annually for forest products (including roundwood products and other uses [see Other removals]). Average annual removals of sawtimber are reported for a period of several years (1980 through 1992 in this report) and are based on information obtained from remeasurement plots (see Survey Procedures in Appendix).

\section{Average net annual growth of growing} stock. - The annual change in volume of sound wood in live sawtimber and poletimber trees and the total volume of trees entering these classes through ingrowth, less volume losses resulting from natural causes.

Average net annual growth of sawtimber.The annual change in the volume of live sawtimber trees and the total volume of trees reaching sawtimber size, less volume losses resulting from natural causes.

Basal area.-Tree area, in square feet, of the cross section at breast height of a single tree. When the basal areas of all trees in a stand are summed, the result is usually expressed as square feet of basal area per acre.

Butt $\log$. - The first 12 to 16 feet from a 1 -foot stump that could be, or is, cut. Minimum standards for butt logs vary by species.

Clear panel.-A section of hardwood tree surface one-fourth the circumference of the tree and at least 2 feet long, free of limbs, knots, bumps, and other indications of defect that preclude clear cuttings.

Commercial species.-Tree species presently or prospectively suitable for industrial wood products. (Note: Excludes species of typically small size, poor form, or inferior quality such as hophornbeam, osage-orange, and redbud.)

County and municipal land.-Land owned by counties and local public agencies or municipalities, or land leased to these governmental units for 50 years or more.

Cropland.-Land under cultivation within the past 24 months; including cropland harvested, crop failures, cultivated summer fallow, idle cropland used only for pasture, orchards, and land in soil improvement crops, but excluding land cultivated in developing improved pasture.

Cull.-Portions of a tree that are unusable for industrial wood products because of rot, missing or dead material, or other defect.

Diameter class. - A classification of trees based on diameter outside bark, measured at breast height (d.b.h.). Two-inch diameter classes are commonly used in Forest Inventory and Analysis, with the even inch the 
approximate midpoint for a class. For example, the 6-inch class includes trees 5.0 through 6.9 inches d.b.h.

Diameter at breast height (d.b.h.). - The outside bark diameter at 4.5 feet $(1.37 \mathrm{~m})$ above the forest floor on the uphill side of the tree. For determining breast height, the forest floor includes the duff layer that may be present, but does not include unincorporated woody debris that may rise above the ground line.

Face.-A section of the tree surface one-fourth the circumference of the tree extending the full length of the log.

Farm.-Any place from which $\$ 1,000$ or more of agricultural products were produced and sold during the year.

Farmer-owned land.-Land owned by farm operators whether part of the farmstead or not. (Note: Excludes land leased by farm operators from nonfarm owners, such as railroad companies and States.)

Forest industry land.-Land owned by companies or individuals operating wood-using plants.

Forest land.-Land at least 16.7 percent stocked by forest trees of any size, or formerly having had such tree cover, and not currently developed for nonforest use. (Note: Stocking is measured by comparing specified standards with basal area and/or number of trees, age or size, and spacing.) The minimum area for classification of forest land is 1 acre. Roadside, streamside, and shelterbelt strips of timber must have a crown width of at least 120 feet to qualify as forest land. Unimproved roads and trails, streams, or other bodies of water or clearings in forest areas shall be classed as forest if less than 120 feet wide. (See definitions for Land, Timberland, Reserved forest land, Stocking, and Water.)

Forest type.-A classification of forest land based on the species forming a plurality of live tree stocking. Major forest types in the State are:

Jack pine.-Forests in which jack pine comprises a plurality of the stocking. (Common associates include eastern white pine, red pine, aspen, birch, and maple.)
Red pine.-Forests in which red pine comprises a plurality of the stocking. (Common associates include eastern white pine, jack pine, aspen, birch, and maple.)

Eastern white pine.-Forests in which eastern white pine comprises a plurality of the stocking. (Common associates include red pine, jack pine, aspen, birch, and maple.)

Balsam fir.-Forests in which balsam fir and white spruce comprise a plurality of the stocking with balsam fir the most common. (Common associates include white spruce, aspen, maple, birch, northern white-cedar, and tamarack.)

White spruce.-Forests in which white spruce and balsam fir comprise a plurality of the stocking with white spruce the most common. (Common associates include balsam fir, aspen, maple, birch, northern white-cedar, and tamarack.)

Black spruce.-Forests in which swamp conifers comprise a plurality of the stocking with black spruce the most common. (Common associates include tamarack and northern white-cedar.)

Northern white-cedar.-Forests in which swamp conifer species comprise a plurality of the stocking with northern white-cedar the most common. (Common associates include tamarack and black spruce.)

Tamarack.-Forests in which swamp conifers comprise a plurality of the stocking with tamarack the most common. (Common associates include black spruce and northern white-cedar.)

Oak-hickory.-Forests in which northern red oak, white oak, bur oak, or hickories, singly or in combination, comprise a plurality of the stocking. (Common associates include jack pine, beech, yellow-poplar, elm, and maple.)

Elm-ash-soft maple.-Forests in which lowland elm, ash, red maple, silver maple, and cottonwood, singly or in combination, comprise a plurality of the stocking. (Common associates include birch, spruce, and balsam fir.)

Maple-birch.-Forests in which sugar maple, basswood, yellow birch, upland American elm, and red maple, singly or in combination, comprise a plurality of the stocking. (Common associates include birch, spruce, and balsam fir.)

Aspen.-Forests in which quaking aspen or bigtooth aspen, singly or in combination, 
comprise a plurality of the stocking. (Common associates include balsam poplar, balsam fir, and paper birch.)

Paper birch.-Forests in which paper birch comprises a plurality of the stocking. (Common associates include maple, aspen, and balsam fir.)

Balsam poplar.-Forests in which balsam poplar comprises a plurality of the stocking. (Common associates include aspen, elm, and ash.)

Growing-stock tree.-A live tree of commercial species that meets specified standards of size, quality, and merchantability. (Note: Excludes rough, rotten, and dead trees.)

Growing-stock volume.-Net volume in cubic feet of growing-stock trees 5.0 inches d.b.h. and over, from 1 foot above the ground to a minimum 4.0 inch top diameter (outside bark) of the central stem or to the point where the central stem breaks into limbs.

Hard hardwoods.- Hardwood species with an average specific gravity greater than 0.50 such as oaks, hard maple, and hickories.

Hardwoods.-Dicotyledonous trees, usually broad-leaved and deciduous. (See Soft hardwoods and Hard hardwoods.)

Improved pasture.-Land currently improved for grazing by cultivation, seeding, irrigation, or clearing of trees and brush.

Indian owned land.-Land owned by Native Americans or land held in trust by the United States for tribes or individual Native Americans.

Industrial wood.-All roundwood products except residential fuelwood.

Land.-A. Bureau of the Census. Dry land and land temporarily or partly covered by water such as marshes, swamps, and river flood plains (except tidal flats below mean high tide); streams, sloughs, estuaries, and canals less than one-eighth of a statute mile wide; and lakes, reservoirs, and ponds less than 40 acres in area.

B. Forest Inventory and Analysis. The same as the Bureau of the Census, except minimum width of streams, etc., is 120 feet and minimum size of lakes, etc., is less than 1 acre.
Live trees.-Growing-stock, rough, and rotten trees 1.0 inch d.b.h. and larger.

Log grade.-A log classification based on external characteristics as indicators of quality or value. (See Appendix for specific grading factors used.)

Marsh.-Nonforest land that characteristically supports low, generally herbaceous or shrubby vegetation and that is intermittently covered with water.

Merchantable.-Refers to a pulpwood or sawlog section that meets pulpwood or saw-log specifications, respectively.

Miscellaneous Federal land.-Federal land other than National Forest.

Miscellaneous private corporation.-Lands privately owned by any coporation other than forest industry or farmer.

Miscellaneous private land.-Privately owned land other than forest-industry, miscellaneous private corporation and farmer-owned land.

Mortality.-The volume of sound wood in growing-stock and sawtimber trees that die annually.

National Forest land.-Federal land that has been legally designated as National Forest or purchase units, and other land administered by the USDA Forest Service.

Net volume.-Gross volume less deductions for rot, sweep, or other defect affecting use for timber products.

Noncommercial species.-Tree species of typically small size, poor form, or inferior quality that normally do not develop into trees suitable for industrial wood products. Classified in volume tables as rough trees.

Nonforest land.-Land that has never supported forests, and land formerly forested where use for timber management is precluded by development for other uses. (Note: Includes areas used for crops, improved pasture, residential areas, city parks, improved roads of any width and adjoining clearings, powerline clearings of any width, 
and 1- to 39.9-acre areas of water classified by the Bureau of the Census as land. If intermingled in forest areas, unimproved roads and nonforest strips must be more than 120 feet wide and more than 1 acre in area to qualify as nonforest land.)

a. Nonforest land without trees.-Nonforest land with no live trees present.

b. Nonforest land with trees.-Nonforest land with one or more trees per acre at least 5 inches d.b.h.

Nonstocked land.-Forest land less than 16.7 percent stocked with live trees.

Other removals.-Growing-stock trees removed but not utilized for products, or trees left standing but "removed" from the timberland classification by land use change.

Examples are removals from cultural operations such as timber stand improvement work, land clearing, and changes in land use.

Ownership size class.-The amount of timberland owned by one owner, regardless of the number of parcels.

Pasture.-Land presently used for grazing or under cultivation to develop grazing.

Poletimber stand.-(See Stand-size class.)

Poletimber tree.-A tree of commercial species at least 5.0 inches d.b.h. but smaller than sawtimber size (9.0 inches d.b.h. for softwoods, 11.0 inches d.b.h. for hardwoods).

Potential productivity class.-A classification of forest lands in terms of inherent capacity to grow crops of industrial wood. The class identifies the potential growth in merchantable cubic feet/acre/year at culmination of mean annual increment of fully stocked natural stands.

Reserved forest land.-Forest land withdrawn from timber utilization through statute, administrative regulation, designation, or exclusive use for Christmas tree production, as indicated by annual shearing.

Rotten tree.-A tree that does not meet regional merchantability standards because of excessive unsound cull.
Rough tree.-A tree that does not meet regional merchantability standards because of excessive sound cull. May include noncommercial tree species.

Roundwood products.-Logs, bolts or other round sections (including chips from roundwood) cut from trees for industrial or consumer uses. (Note: Includes saw logs, veneer logs and bolts; cooperage logs and bolts; pulpwood; fuelwood; pilings; poles; posts; hewn ties; mine timbers; and various other round, split, or hewn products.)

Salvable dead tree.-A standing or down dead tree considered merchantable by regional standards.

Sapling.-A live tree 1.0 to 5.0 inches d.b.h.

Sapling-seedling stand.-(See Stand-size class.)

Saw log.-A log meeting minimum standards of diameter, length, and defect. A saw log must be at least 8 feet long, sound, straight, have a minimum diameter outside bark (d.o.b.) of 7.0 inches for softwoods and 9.0 inches for hardwoods, or have other combinations of size and defect specified by regional standards.

Saw-log portion.-That part of the bole of sawtimber trees between the stump and the saw-log top.

Saw-log top.-The point on the bole of sawtimber trees above which a saw log cannot be produced. The minimum saw-log top is 7.0 inches d.o.b. for softwoods and 9.0 inches d.o.b. for hardwoods.

Sawtimber stand.-(See Stand-size class.)

Sawtimber tree.-A tree of commercial species containing at least a 12 -foot saw log or two noncontiguous saw logs 8 feet or longer, and meeting regional specifications for freedom from defect. Softwoods must be at least 9.0 inches d.b.h. Hardwoods must be at least 11.0 inches d.b.h.

Sawtimber volume.-Net volume of the sawlog portion of live sawtimber in board feet, International 1/4-inch rule (unless specified 
otherwise), from the stump to a minimum 7 inches top d.o.b. for softwoods and a minimum 9 inches top d.o.b. for hardwoods.

Seedling.-A live tree less than 1.0 inch d.b.h. that is expected to survive. Only softwood seedlings more than 6 inches tall and hardwood seedlings more than 1 foot tall are counted.

Short-log (rough tree).-Sawtimber-size trees of commercial species that contain at least one merchantable 8 - to 11 -foot saw log but not a 12 -foot saw log.

Site index.-An expression of forest site quality based on the height of a free-growing dominant, or codominant tree of a representative species in the forest type at age 50 .

Soft hardwoods.-Hardwood species with an average specific gravity less than 0.50 such as gum, yellow-poplar, cottonwood, red maple, basswood, and willow.

Softwoods.-Coniferous trees, usually evergreen, having needles or scale-like leaves.

Stand.-A group of trees on a minimum of 1 acre of forest land that is stocked by forest trees of any size.

Stand-age class.-Age of main stand. Main stand refers to trees of the dominant forest type and stand-size class.

Stand-size class.-A classification of stocked (see Stocking) forest land based on the size class of live trees on the area; that is, sawtimber, poletimber, or seedlings and saplings.

a. Sawtimber stands.-Stands with half or more of live stocking in sawtimber or poletimber trees, and with sawtimber stocking at least equal to poletimber stocking.

b. Poletimber stands.-Stands with half or more live stocking in poletimber and/or sawtimber trees, and with poletimber stocking exceeding that of sawtimber.

c. Sapling-seedling stands.-Stands with more than half of the live stocking in saplings and/or seedlings.

State land.-Land owned by States, or leased to them for 50 years or more.
Stocking.-The degree of occupancy of land by live trees, measured by basal area; and/or the number of trees in a stand by size or age and spacing, compared to the basal area; and/or number of trees required to fully utilize the growth potential of the land; that is, the stocking standard.

A stocking percent of 100 indicates full utilization of the site and is equivalent to 80 square feet of basal area per acre in trees 5.0 inches d.b.h. and larger. In a stand of trees less than 5.0 inches d.b.h., a stocking percent of 100 would indicate that the present number of trees is sufficient to produce 80 square feet of basal area per acre when the trees reach 5.0 inches d.b.h.

Stands are grouped into the following stocking classes:

Overstocked stands.-Stands in which stocking of live trees is 133 percent or more.

Fully stocked stands.-Stands in which stocking of live trees is from 100.0 to 132.9 percent.

Medium stocked stands.--Stands in which stocking of live trees is from 60.0 to 99.9 percent.

Poorly stocked stands.-Stands in which stocking of live trees is from 16.7 to 59.9 percent.

Nonstocked areas. - Timberland on which stocking of live trees is less than 16.7 percent.

Timberland.-Forest land that is producing, or capable of producing, in excess of 20 cubic feet per acre per year of industrial wood crops under natural conditions. In addition, the forest land must not be withdrawn from timber utilization, and not associated with urban or rural development. Currently inaccessible and inoperable areas are included.

Tree.-A woody plant usually having one or more perennial stems, a more or less definitely formed crown of foliage, and a height of at least 12 feet at maturity.

Tree grade.-A tree classification based on external characteristics as indicators of quality or value, used for hardwood species. (See Appendix for specific grading factors used.) 
Tree size class.-A classification of trees based on diameter at breast height, including sawtimber trees, poletimber trees, saplings, and seedlings.

Unproductive forest land.-Forest land incapable of producing 20 cubic feet per acre per year of industrial wood under natural conditions because of adverse site conditions. (Note: Adverse conditions include sterile soils, dry climate, poor drainage, high elevation, steepness, and rockiness.)

Upper stem portion. - That part of the bole of sawtimber trees above the saw-log top to a minimum top diameter of 4.0 inches outside bark, or to the point where the central stem breaks into limbs.

Water.-(a) Bureau of the Census.-Permanent inland water surfaces, such as lakes, reservoirs, and ponds at least 40 acres in area; and streams, sloughs, estuaries, and canals at least one-eighth of a statute mile wide.

(b) Noncensus.-Permanent inland water surfaces, such as lakes, reservoirs, and ponds from 1 to 39.9 acres in area; and streams, sloughs, estuaries, and canals from 120 feet to one-eighth of a statute mile wide.

Wooded pasture.-Improved pasture with more than 16.7 percent stocking in live trees but less than 25 percent stocking in growing-stock trees. Area is currently improved for grazing or there is evidence of grazing.

\section{LITERATURE CITED}

Belcher, David W.; Holdaway, Margaret R.; Brand, Gary J. 1982. A description of STEMS the stand and tree evaluation and modeling system. Gen. Tech. Rep. NC-79. St. Paul, MN: U.S. Department of Agriculture, Forest Service, North Central Forest Experiment Station. 18 p.

Campbell, Robert A. 1964. Forest Service log grades for southern pine. Res. Pap. SE-11. Asheville, NC: U.S. Department of Agriculture, Forest Service, Southeastern Forest Experiment Station. 17 p.

Chase, Clarence D.; Pfeifer, Ray E. 1970. The growing timber resource of Michigan, 1966 - Unit 1- Eastern Upper Peninsula.
St. Paul, MN: U.S. Department of Agriculture, Forest Service, Lake States Forest Experiment Station; Lansing, MI: Michigan Department of Natural Resources. 63 p.

Hackett, Ronald L.; Pilon, John. 1993. Michigan timber industry - an assessment of timber product output and use, 1990. Resour. Bull. NC-144. St. Paul, MN: U.S. Department of Agriculture, Forest Service, North Central Forest Experiment Station. $56 \mathrm{p}$.

Hahn, Jerold T. 1984. Tree volume and biomass equations for the Lake States. Res. Pap. NC-250. St. Paul, MN: U.S. Department of Agriculture, Forest Service, North Central Forest Experiment Station. 10 p.

Hanks, Leland F. 1976. Hardwood tree grades for factory lumber. Res. Pap. NE333. Broomall, PA: U.S. Department of Agriculture, Forest Service, Northeastern Forest Experiment Station. $81 \mathrm{p}$.

Hansen, Mark H. 1990. A comprehensive sampling system for forest inventory based on an individual tree growth model.

St. Paul, MN: University of Minnesota, College of Natural Resources. 256 p. Ph.D. dissertation.

Little, Elbert L. 1981. Checklist of native and naturalized trees of the United States. Agric. Handb. 541. Washington, DC: U.S. Department of Agriculture, Forest Service. $385 \mathrm{p}$.

Loetsch, F.; Haller, K.E. 1964. Forest inventory, volume 1, statistics of forest inventory and information from aerial photographs. BLV Verlagsgesellschaft Munch Basle Vienna. 436 p.

Ostrander, Myron D.; Brisbin, Robert L. 1971. Sawlog grades for eastern white pine. Res. Pap. NE-205. Upper Darby, PA: U.S. Department of Agriculture, Forest Service, Northeastern Forest Experiment Station. 24 p.

Rast, Everette D.; Sonderman, David L.; Gammon, Glenn L. 1973. A guide to hardwood log grading. Gen. Tech. Rep. NE-1. Upper Darby, PA: U.S. Department of Agriculture, Forest Service, Northeastern Forest Experiment Station. 31 p. 
Smith, W. Brad. 1983. Adjusting the STEMS regional growth models to improve local predictions. Res. Note NC-297. St. Paul, MN: U.S. Department of Agriculture, Forest Service, North Central Forest Experiment Station. 5 p.

VanDeusen, P.C.; Dell, T.R.; Thomas, C.E. 1986. Volume growth estimation from permanent horizontal points. Forest Science. 32: 415-422.

Wiant, Harry V., Jr.; Castenaeda, Froylan. 1977. Mesavage and Girard's volume tables formulated. BLM4. Denver, CO: U.S. Department of Interior, Bureau of Land Management, Denver Service Center: 1- 4.

\section{TABLE TITLES}

\section{Area}

Table 1.-Area by county and major land-use class, Southern Lower Peninsula, Michigan, 1993

Table 2.-Area of timberland by county and ownership class, Southern Lower Peninsula, Michigan, 1993

Table 3.-Area of timberland by county and forest type, Southern Lower Peninsula, Michigan, 1993

Table 4.-Area of timberland by county and stand-size class, Southern Lower Peninsula, Michigan, 1993

Table 5.-Area of timberland by county and potential productivity class, Southern Lower Peninsula, Michigan, 1993

Table 6.-Area of timberland by county and stocking class of growing-stock trees, Southern Lower Peninsula, Michigan, 1993

Table 7.-Area of timberland by forest type and ownership class, Southern Lower Peninsula, Michigan, 1993

Table 8.-Area of timberland by ownership class and stocking class of growingstock trees, Southern Lower Peninsula, Michigan, 1993
Table 9.-Area of timberland by forest type and stand-size class, Southern Lower Peninsula, Michigan, 1993

\section{Number of Trees}

Table 10.-Number of all live trees on timberland by species group and diameter class, Southern Lower Peninsula, Michigan, 1993

Table 11.-Number of growing-stock trees on timberland by species group and diameter class, Southern Lower Peninsula, Michigan, 1993

\section{Volume}

Table 12.-Net volume of growing-stock trees on timberland by species group and diameter class, Southern Lower Peninsula, Michigan, 1993

Table 13.-Net volume of growing-stock in the saw-log portion of sawtimber trees on timberland by species group and diameter class, Southern Lower Peninsula, Michigan, 1993

Table 14.-Net volume of sawtimber trees on timberland by species group and diameter class, Southern Lower Peninsula, Michigan, 1993

Table 15.-Net volume of growing-stock and sawtimber on timberland by county and species group, Southern Lower Peninsula, Michigan, 1993

Table 16.-Net volume of timber on timberland by class of timber and major species group, Southern Lower Peninsula, Michigan, 1993

Table 17.-Net volume of live and growingstock trees on timberland by ownership class and major species group, Southern Lower Peninsula, Michigan, 1993

\section{Growth, Removals, and Mortality}

Table 18.-Average annual net growth of growing stock and sawtimber on timberland by county and major species group, Southern Lower Peninsula, Michigan, 1980-1992 
Table 19.-Average annual removals of growing stock and sawtimber on timberland by county and major species group, Southern Lower Peninsula, Michigan, 1980-1992

Table 20.-Average annual net growth, average annual mortality, and average annual removals of growing stock and sawtimber on timberland by species group, Southern Lower Peninsula, Michigan, 1980-1992

Table 21.-Average annual net growth and average annual removals of growing stock on timberland by ownership class and major species group, Southern Lower Peninsula, Michigan, 1980-1992

Table 22.-Average annual net growth and average annual removals of sawtimber on timberland by ownership class and major species group, Southern Lower Peninsula, Michigan, 1980-1992
Table 23.-Current annual net growth, current annual mortality, and 1990 removals of growing stock and sawtimber on timberland by species group, Southern Lower Peninsula, Michigan, 1992

\section{Log Grade}

Table 24.-Net volume of sawtimber trees on timberland by species group and butt log grade or tree grade, Southern Lower Peninsula, Michigan, 1993

\section{Other}

Table 25.-Comparison of adjusted 1980 and 1993 area and growing-stock volume by forest type, Southern Lower Peninsula, Michigan. 
Table 1.--Area by county and major land-use class,

Southem Lower Peninsula, Michigan, 1993

(In thousand acres)

\begin{tabular}{|c|c|c|c|c|c|c|}
\hline \multirow[b]{2}{*}{ County } & \multirow[b]{2}{*}{$\begin{array}{l}\text { Total } \\
\text { area } \\
\end{array}$} & \multicolumn{3}{|c|}{ Forest land } & \multirow[b]{2}{*}{$\begin{array}{r}\begin{array}{r}\text { Nonforest } \\
\text { land }\end{array} \\
\end{array}$} & \multirow[b]{2}{*}{$\begin{array}{r}\text { Census } \\
\text { water }\end{array}$} \\
\hline & & $\begin{array}{r}\text { All } \\
\text { forest } \\
\text { land } \\
\end{array}$ & Timberland & $\begin{array}{r}\text { Reserved } \\
\text { timber- } \\
\text { land }\end{array}$ & & \\
\hline Allegan & $1,173.4$ & 179.9 & 178.4 & 1.5 & 349.7 & 643.8 \\
\hline Barry & 369.2 & 111.2 & 111.2 & -. & 244.7 & 13.3 \\
\hline Berrien & $1,012.1$ & 68.3 & 67.0 & 1.3 & 297.1 & 646.7 \\
\hline Branch & 332.5 & 54.4 & 54.4 & -. & 270.4 & 7.7 \\
\hline Calhoun & 459.8 & 111.0 & 110.6 & 0.4 & 342.6 & 6.2 \\
\hline Cass & 325.4 & 76.9 & 76.9 & -. & 238.1 & 10.4 \\
\hline Clinton & 367.7 & 55.4 & 53.8 & 1.6 & 310.3 & 2.0 \\
\hline Eaton & 370.6 & 82.1 & 82.1 & -- & 286.9 & 1.6 \\
\hline Genesee & 415.6 & 64.9 & 64.9 & -- & 344.5 & 6.2 \\
\hline Gratiot & 365.8 & 49.2 & 49.2 & -- & 315.7 & 0.9 \\
\hline Hillsdale & 388.6 & 74.1 & 74.1 & -- & 309.2 & 5.3 \\
\hline Huron & $1,367.8$ & 66.2 & 64.5 & 1.7 & 469.2 & 832.4 \\
\hline Ingham & 359.0 & 62.0 & 62.0 & -- & 295.9 & 1.1 \\
\hline Ionia & 371.4 & 74.6 & 74.6 & -- & 292.3 & 4.5 \\
\hline Jackson & 463.2 & 82.3 & 82.3 & -- & 369.9 & 11.0 \\
\hline Kalamazoo & 371.3 & 79.0 & 75.0 & 4.0 & 280.6 & 11.7 \\
\hline Kent & 558.2 & 155.5 & 155.5 & -- & 392.5 & 10.2 \\
\hline Lapeer & 424.4 & 110.3 & 109.4 & 0.9 & 308.5 & 5.6 \\
\hline Lenawee & 487.3 & 55.2 & 55.2 & -- & 425.2 & 6.9 \\
\hline Livingston & 374.7 & 100.0 & 94.1 & 5.9 & 263.8 & 10.9 \\
\hline Macomb & 364.7 & 61.4 & 60.6 & 0.8 & 246.1 & 57.2 \\
\hline Monroe & 435.3 & 37.9 & 37.9 & -- & 314.9 & 82.5 \\
\hline Montcalm & 461.5 & 133.0 & 133.0 & $-\cdot$ & 320.2 & 8.3 \\
\hline Muskegon & 933.9 & 162.2 & 159.9 & 2.3 & 163.6 & 608.1 \\
\hline Oakland & 581.2 & 137.4 & 111.2 & 26.2 & 421.2 & 22.6 \\
\hline Ottawa & $1,044.6$ & 79.1 & 79.1 & -- & 283.0 & 682.5 \\
\hline Saginaw & 522.1 & 98.9 & 98.9 & -- & 418.8 & 4.4 \\
\hline St. Clair & 532.8 & 79.7 & 78.3 & 1.4 & 383.9 & 69.2 \\
\hline St. Joseph & 333.6 & 65.6 & 65.6 & -- & 256.8 & 11.2 \\
\hline Sanilac & $1,018.0$ & 79.9 & 79.9 & -- & 537.0 & 401.1 \\
\hline Shiawassee & 346.1 & 50.2 & 50.2 & -- & 294.7 & 1.2 \\
\hline Tuscola & 584.9 & 115.5 & 115.5 & -- & 404.6 & 64.8 \\
\hline Van Buren & 697.8 & 122.3 & 122.3 & -- & 268.8 & 306.7 \\
\hline Washtenaw & 462.5 & 82.2 & 82.2 & -- & 372.3 & 8.0 \\
\hline Wayne & 430.2 & 35.9 & 30.9 & 5.0 & 357.1 & 37.2 \\
\hline All counties & $19,107.2$ & $3,053.7$ & $3,000.7$ & 53.0 & $11,450.1$ & $4,603.4$ \\
\hline
\end{tabular}


Table 2.--Area of timberland by county and ownership class,

Southem Lower Peninsula, Michigan, 1993

(In thousand acres)

\begin{tabular}{|c|c|c|c|c|c|c|}
\hline \multirow[b]{2}{*}{ County } & \multicolumn{6}{|c|}{ Ownership class } \\
\hline & $\begin{array}{r}\text { All } \\
\text { owners } \\
\end{array}$ & $\begin{array}{r}\text { National } \\
\text { forest }\end{array}$ & State & $\begin{array}{r}\text { County } \\
\text { and } \\
\text { municipal } \\
\end{array}$ & $\begin{array}{r}\text { Misc. } \\
\text { private- } \\
\text { corporation }\end{array}$ & $\begin{array}{r}\text { Misc. private- } \\
\text { individual } \\
\text { farmer }\end{array}$ \\
\hline Allegan & 178.4 & - & 55.8 & - & 8.0 & 114.6 \\
\hline Barry & 111.2 & -- & 19.8 & $-\cdot$ & - & 91.4 \\
\hline Berrien & 67.0 & -- & 2.7 & 9.6 & 5.4 & 49.3 \\
\hline Branch & 54.4 & - & - & 3.0 & $\cdots$ & 51.4 \\
\hline Calhoun & 110.6 & - & - & -- & 7.6 & 103.0 \\
\hline Cass & 76.9 & -- & $\cdots$ & - & 8.1 & 68.8 \\
\hline Clinton & 53.8 & - & $\cdots$ & 2.6 & 7.4 & 43.8 \\
\hline Eaton & 82.1 & -- & - & - & 28.9 & 53.2 \\
\hline Genesee & 64.9 & -- & - & 3.7 & - & 61.2 \\
\hline Gratiot & 49.2 & -- & 7.3 & -- & - & 41.9 \\
\hline Hillsdale & 74.1 & - & - & - & - & 74.1 \\
\hline Huron & 64.5 & - & 9.7 & 2.8 & - & 52.0 \\
\hline Ingham & 62.0 & -- & 3.6 & -- & 3.7 & 54.7 \\
\hline Ionia & 74.6 & -- & 4.0 & 3.8 & - & 66.8 \\
\hline Jackson & 82.3 & - & 13.1 & 2.6 & 8.1 & 58.5 \\
\hline Kalamazoo & 75.0 & - & 6.2 & 5.8 & $\cdots$ & 63.0 \\
\hline Kent & 155.5 & -- & 1.5 & -- & 8.3 & 145.7 \\
\hline Lapeer & 109.4 & -- & 15.8 & 2.9 & 10.4 & 80.3 \\
\hline Lenawee & 55.2 & $\cdots$ & - & -- & 2.2 & 53.0 \\
\hline Livingston & 94.1 & - & 5.6 & - & 17.6 & 70.9 \\
\hline Macomb & 60.6 & -- & 2.4 & 9.0 & 29.5 & 19.7 \\
\hline Monroe & 37.9 & - & 1.5 & -- & 6.3 & 30.1 \\
\hline Montcalm & 133.0 & 1.8 & 18.5 & 5.9 & 10.3 & 96.5 \\
\hline Muskegon & 159.9 & 12.4 & 8.8 & 21.8 & 15.5 & 101.4 \\
\hline Oakland & 111.2 & $\cdots$ & - & $\cdots$ & 32.0 & 79.2 \\
\hline Ottawa & 79.1 & $\cdots$ & - & 5.1 & 9.0 & 65.0 \\
\hline Saginaw & 98.9 & - & 9.6 & - & -- & 89.3 \\
\hline St. Clair & 78.3 & -- & 11.0 & -- & 16.2 & 51.1 \\
\hline St. Joseph & 65.6 & - & 4.6 & - & -. & 61.0 \\
\hline Sanilac & 79.9 & $\cdots$ & 2.9 & - & 8.7 & 68.3 \\
\hline Shiawassee & 50.2 & - & - & - & 3.0 & 47.2 \\
\hline Tuscola & 115.5 & -- & 21.2 & $\cdots$ & - & 94.3 \\
\hline Van Buren & 122.3 & $\cdots$ & - & 1.1 & 3.3 & 117.9 \\
\hline Washtenaw & 82.2 & - & 12.4 & 3.5 & 6.8 & 59.5 \\
\hline Wayne & 30.9 & $\cdots$ & - & 2.4 & 3.5 & 25.0 \\
\hline All counties & $3,000.7$ & 14.2 & 238.0 & 85.6 & 259.8 & $2,403.1$ \\
\hline
\end{tabular}




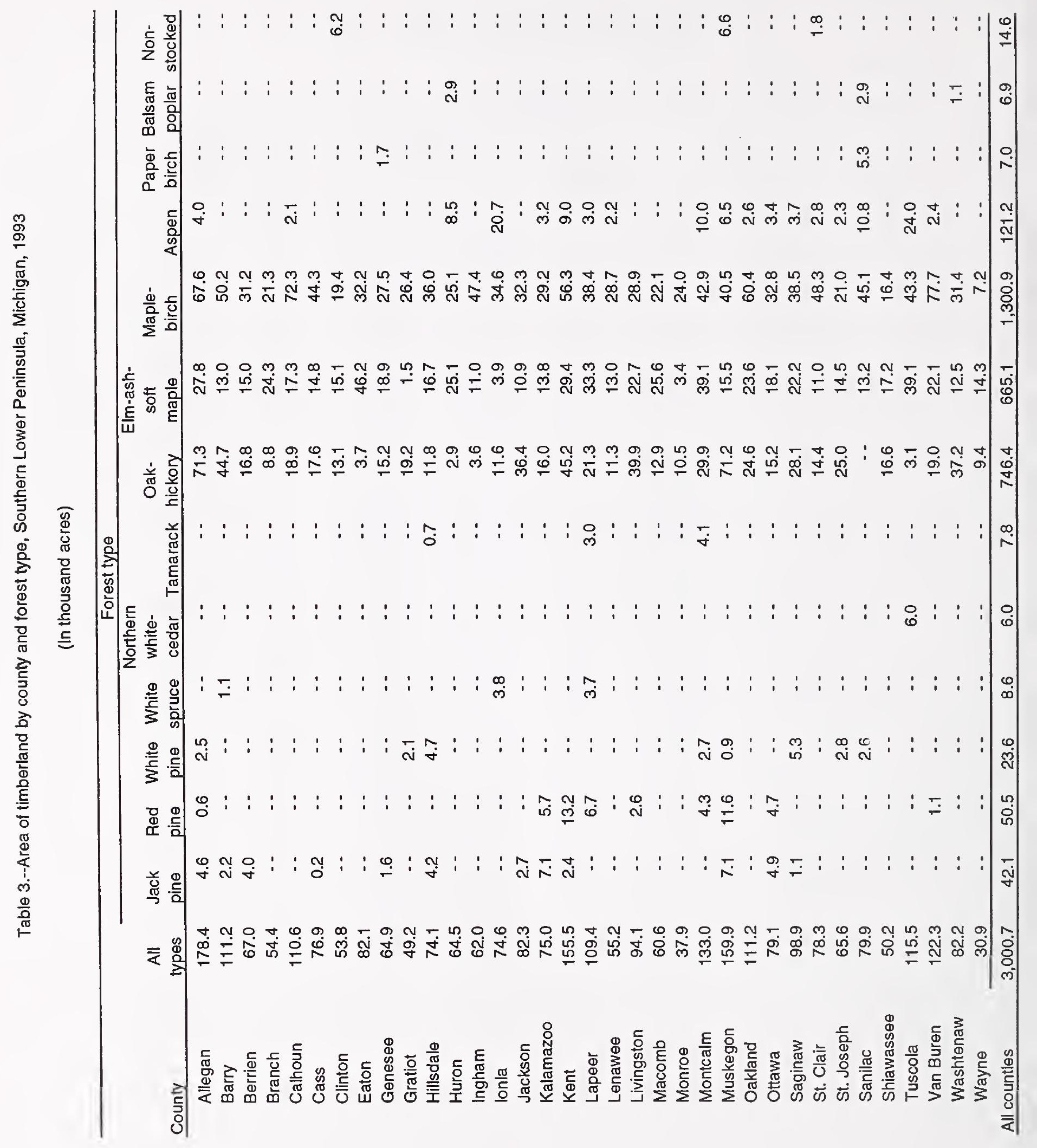


Table 4.--Area of timberland by county and stand-size class,

Southern Lower Peninsula, Michigan, 1993

(In thousand acres)

\begin{tabular}{|c|c|c|c|c|c|}
\hline \multirow[b]{2}{*}{ County } & \multirow[b]{2}{*}{ All stands } & \multicolumn{4}{|c|}{ Stand-size class } \\
\hline & & Sawtimber & Poletimber & $\begin{array}{l}\text { Sapling and } \\
\text { Seedling }\end{array}$ & $\begin{array}{c}\text { Non- } \\
\text { stocked } \\
\end{array}$ \\
\hline Allegan & 178.4 & 111.7 & 35.4 & 31.3 & - \\
\hline Barry & 111.2 & 67.3 & 15.4 & 28.5 & $\cdots$ \\
\hline Berrien & 67.0 & 61.2 & 4.0 & 1.8 & -- \\
\hline Branch & 54.4 & 30.4 & 11.5 & 12.5 & -- \\
\hline Calhoun & 110.6 & 67.8 & 30.8 & 12.0 & -- \\
\hline Cass & 76.9 & 50.7 & 22.2 & 4.0 & -- \\
\hline Clinton & 53.8 & 22.8 & 10.4 & 14.4 & 6.2 \\
\hline Eaton & 82.1 & 48.5 & 33.6 & -- & - \\
\hline Genesee & 64.9 & 27.2 & 8.1 & 29.6 & - \\
\hline Gratiot & 49.2 & 29.3 & 5.5 & 14.4 & - \\
\hline Hillsdale & 74.1 & 39.3 & 21.8 & 13.0 & -- \\
\hline Huron & 64.5 & 37.4 & 15.3 & 11.8 & -- \\
\hline Ingham & 62.0 & 43.1 & 7.9 & 11.0 & -- \\
\hline Ionia & 74.6 & 38.4 & 36.2 & $\cdots$ & - \\
\hline Jackson & 82.3 & 66.0 & 8.0 & 8.3 & - \\
\hline Kalamazoo & 75.0 & 42.7 & 18.3 & 14.0 & -- \\
\hline Kent & 155.5 & 83.7 & 34.7 & 37.1 & -- \\
\hline Lapeer & 109.4 & 51.6 & 21.9 & 35.9 & $\cdots$ \\
\hline Lenawee & 55.2 & 33.2 & 13.3 & 8.7 & -- \\
\hline Livingston & 94.1 & 84.3 & 4.6 & 5.2 & -- \\
\hline Macomb & 60.6 & 19.1 & 19.1 & 22.4 & -- \\
\hline Monroe & 37.9 & 27.2 & 9.7 & 1.0 & $\cdots$ \\
\hline Montcalm & 133.0 & 83.2 & 32.3 & 17.5 & -- \\
\hline Muskegon & 159.9 & 86.0 & 39.6 & 27.7 & 6.6 \\
\hline Oakland & 111.2 & 52.8 & 27.3 & 31.1 & -- \\
\hline Ottawa & 79.1 & 50.7 & 19.0 & 9.4 & $\cdots$ \\
\hline Saginaw & 98.9 & 31.8 & 38.1 & 29.0 & - \\
\hline St. Clair & 78.3 & 46.4 & 15.2 & 14.9 & 1.8 \\
\hline St. Joseph & 65.6 & 48.2 & 9.2 & 8.2 & -- \\
\hline Sanilac & 79.9 & 19.1 & 19.9 & 40.9 & -- \\
\hline Shiawassee & 50.2 & 36.2 & 5.4 & 8.6 & -- \\
\hline Tuscola & 115.5 & 34.0 & 36.4 & 45.1 & -- \\
\hline Van Buren & 122.3 & 73.9 & 18.4 & 30.0 & - \\
\hline Washtenaw & 82.2 & 60.0 & 6.7 & 15.5 & $\cdots$ \\
\hline Wayne & 30.9 & 18.9 & 7.9 & 4.1 & 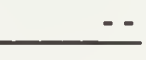 \\
\hline All counties & $3,000.7$ & $1,724.1$ & 663.1 & 598.9 & 14.6 \\
\hline
\end{tabular}


Table 5.--Area of timberland by county and potential productivity class, Southern Lower Peninsula, Michigan, 1993

(In thousand acres)

\begin{tabular}{|c|c|c|c|c|c|c|}
\hline \multirow[b]{2}{*}{ County } & \multirow[b]{2}{*}{ All classes } & \multicolumn{5}{|c|}{$\begin{array}{l}\text { Potential productivity class } \\
\text { (cubic feet of growth per acre per year) }\end{array}$} \\
\hline & & $165+$ & $120-164$ & $85-119$ & $50-84$ & $20-49$ \\
\hline Allegan & 178.4 & 7.9 & 5.9 & 59.2 & 86.1 & 19.3 \\
\hline Barry & 111.2 & 7.8 & 8.3 & 50.7 & 34.1 & 10.3 \\
\hline Berrien & 67.0 & 6.9 & 6.7 & 38.4 & 15.0 & $\ldots$ \\
\hline Branch & 54.4 & - & 6.1 & 29.3 & 19.0 & -- \\
\hline Calhoun & 110.6 & 3.8 & 7.5 & 60.7 & 38.6 & - \\
\hline Cass & 76.9 & 4.3 & 9.1 & 37.7 & 20.8 & 5.0 \\
\hline Clinton & 53.8 & - & -- & 25.7 & 17.1 & 11.0 \\
\hline Eaton & 82.1 & 3.6 & 11.0 & 42.7 & 24.8 & $\cdots$ \\
\hline Genesee & 64.9 & -- & 3.7 & 37.7 & 18.5 & 5.0 \\
\hline Gratiot & 49.2 & $\ldots$ & $\cdots$ & 29.4 & 15.9 & 3.9 \\
\hline Hillsdale & 74.1 & - & 12.9 & 31.4 & 24.4 & 5.4 \\
\hline Hurori & 64.5 & - & 8.6 & 17.3 & 27.0 & 11.6 \\
\hline Ingham & 62.0 & 3.6 & 7.2 & 40.2 & 9.3 & 1.7 \\
\hline Ionia & 74.6 & 3.8 & 15.5 & 19.1 & 36.2 & $\cdots$ \\
\hline Jackson & 82.3 & 5.4 & 8.0 & 35.2 & 23.9 & 9.8 \\
\hline Kalamazoo & 75.0 & 5.9 & 9.6 & 25.9 & 23.8 & 9.8 \\
\hline Kent & 155.5 & 5.1 & 14.0 & 53.1 & 61.8 & 21.5 \\
\hline Lapeer & 109.4 & $\cdots$ & 9.7 & 47.7 & 37.7 & 14.3 \\
\hline Lenawee & 55.2 & 4.4 & 2.2 & 24.6 & 24.0 & $\therefore$ \\
\hline Livingston & 94.1 & $\cdots$ & -- & 54.8 & 36.3 & 3.0 \\
\hline Macomb & 60.6 & $\cdots$ & 3.9 & 22.9 & 30.0 & 3.8 \\
\hline Monroe & 37.9 & $\cdots$ & -- & 32.5 & 3.9 & 1.5 \\
\hline Montcalm & 133.0 & $\cdots$ & 9.4 & 48.1 & 49.7 & 25.8 \\
\hline Muskegon & 159.9 & -- & 3.4 & 42.1 & 70.7 & 43.7 \\
\hline Oakland & 111.2 & $\cdots$ & 5.6 & 39.9 & 43.4 & 22.3 \\
\hline Ottawa & 79.1 & - & 8.0 & 19.5 & 42.4 & 9.2 \\
\hline Saginaw & 98.9 & $\cdots$ & $\cdots$ & 23.8 & 71.8 & 3.3 \\
\hline St. Clair & 78.3 & $\cdots$ & 4.8 & 47.8 & 25.7 & $\cdots$ \\
\hline St. Joseph & 65.6 & 9.2 & 4.7 & 27.9 & 17.4 & 6.4 \\
\hline Sanilac & 79.9 & $\cdots$ & $\cdots$ & 40.4 & 39.5 & - \\
\hline Shiawassee & 50.2 & $\cdots$ & 2.8 & 33.7 & 13.7 & $\cdots$ \\
\hline Tuscola & 115.5 & 2.6 & - & 43.1 & 63.7 & 6.1 \\
\hline Van Buren & 122.3 & $\cdots$ & 11.2 & 44.8 & 61.7 & 4.6 \\
\hline Washtenaw & 82.2 & $\cdots$ & - & 38.2 & 39.6 & 4.4 \\
\hline Wayne & 30.9 & $\ldots$ & 2.3 & 19.6 & 3.5 & 5.5 \\
\hline All counties & $3,000.7$ & 74.3 & 202.1 & $1,285.1$ & $1,171.0$ & 268.2 \\
\hline
\end{tabular}


Table 6.--Area of timberland by county and stocking class of growing-stock trees ${ }^{1}$, Southern Lower Peninsula, Michigan, 1993

(In thousand acres)

\begin{tabular}{|c|c|c|c|c|c|c|}
\hline \multirow[b]{2}{*}{ County } & \multicolumn{5}{|c|}{ Stocking class of growing-stock trees } & \multirow[b]{2}{*}{$\begin{array}{c}\text { Over- } \\
\text { stocked }\end{array}$} \\
\hline & All classes & $\begin{array}{c}\text { Non-2 } \\
\text { stocked }\end{array}$ & $\begin{array}{c}\text { Poorly } \\
\text { stocked }\end{array}$ & $\begin{array}{l}\text { Moderately } \\
\text { stocked }\end{array}$ & $\begin{array}{c}\text { Fully } \\
\text { stocked }\end{array}$ & \\
\hline Allegan & 178.4 & -- & 27.2 & 57.0 & 70.5 & 23.7 \\
\hline Barry & 111.2 & -- & 23.7 & 32.5 & 41.0 & 14.0 \\
\hline Berrien & 67.0 & -- & 8.1 & 22.2 & 24.4 & 12.3 \\
\hline Branch & 54.4 & -- & 1.9 & 34.5 & 15.0 & 3.0 \\
\hline Calhoun & 110.6 & -. & 14.6 & 51.0 & 41.3 & 3.7 \\
\hline Cass & 76.9 & -- & 4.3 & 42.1 & 17.6 & 12.9 \\
\hline Clinton & 53.8 & 8.8 & 16.9 & 20.4 & 7.7 & - - \\
\hline Eaton & 82.1 & 6.4 & 43.5 & 13.9 & 10.9 & 7.4 \\
\hline Genesee & 64.9 & -. & 18.0 & 19.6 & 14.9 & 12.4 \\
\hline Gratiot & 49.2 & -. & 6.5 & 26.7 & 16.0 & -. \\
\hline Hillsdale & 74.1 & 4.4 & 15.6 & 21.0 & 28.4 & 4.7 \\
\hline Huron & 64.5 & 2.9 & 17.3 & 19.2 & 19.5 & 5.6 \\
\hline Ingham & 62.0 & -. & 8.5 & 28.2 & 25.3 & -- \\
\hline Ionia & 74.6 & - & 28.6 & 19.0 & 23.1 & 3.9 \\
\hline Jackson & 82.3 & - & 18.8 & 36.8 & 21.3 & 5.4 \\
\hline Kalamazoo & 75.0 & 1.3 & 12.2 & 30.8 & 25.0 & 5.7 \\
\hline Kent & 155.5 & 1.1 & 23.7 & 72.5 & 45.7 & 12.5 \\
\hline Lapeer & 109.4 & -. & 25.0 & 71.5 & 12.9 & -- \\
\hline Lenawee & 55.2 & 4.4 & 2.2 & 35.3 & 10.8 & 2.5 \\
\hline Livingston & 94.1 & -. & 30.6 & 42.6 & 18.3 & 2.6 \\
\hline Macomb & 60.6 & 25.7 & 5.2 & 15.2 & 8.2 & 6.3 \\
\hline Monroe & 37.9 & -. & 13.0 & 1.9 & 17.7 & 5.3 \\
\hline Montcalm & 133.0 & -. & 31.7 & 57.2 & 30.8 & 13.3 \\
\hline Muskegon & 159.9 & 6.6 & 18.0 & 53.3 & 69.6 & 12.4 \\
\hline Oakland & 111.2 & 2.6 & 34.8 & 35.1 & 32.9 & 5.8 \\
\hline Ottawa & 79.1 & 7.7 & 10.4 & 33.7 & 22.3 & 5.0 \\
\hline Saginaw & 98.9 & -- & 12.6 & 37.8 & 37.4 & 11.1 \\
\hline St. Clair & 78.3 & 1.8 & 11.5 & 27.6 & 20.2 & 17.2 \\
\hline St. Joseph & 65.6 & 2.7 & 5.4 & 26.9 & 24.9 & 5.7 \\
\hline Sanilac & 79.9 & -. & 24.4 & 39.4 & 10.3 & 5.8 \\
\hline Shiawassee & 50.2 & 3.0 & -. & 21.9 & 19.9 & 5.4 \\
\hline Tuscola & 115.5 & - - & 30.0 & 34.9 & 44.6 & 6.0 \\
\hline Van Buren & 122.3 & 2.5 & 30.9 & 49.7 & 29.3 & 9.9 \\
\hline Washtenaw & 82.2 & 7.4 & 17.0 & 31.0 & 19.8 & 7.0 \\
\hline Wayne & 30.9 & - & 4.1 & 19.8 & 4.7 & 2.3 \\
\hline All counties & $3,000.7$ & 89.3 & 596.2 & $1,182.2$ & 882.2 & 250.8 \\
\hline
\end{tabular}

1 This table is based on the stocking percent of growing-stock trees rather than that of all live trees. To use the definitions of stocking for this table, replace the term "all live" by "growingstock."

2 Timberland insufficiently stocked with growing-stock trees. 
Table 7.--Area of timberland by forest type and ownership class,

Southern Lower Peninsula, Michigan, 1993

(In thousand acres)

\begin{tabular}{|c|c|c|c|c|c|c|}
\hline \multirow[b]{2}{*}{ Forest type } & \multicolumn{6}{|c|}{ Ownership class } \\
\hline & $\begin{array}{r}\text { All } \\
\text { owners } \\
\end{array}$ & $\begin{array}{r}\text { National } \\
\text { forest } \\
\end{array}$ & State & $\begin{array}{r}\text { County } \\
\text { and } \\
\text { municipal } \\
\end{array}$ & $\begin{array}{r}\text { Misc. } \\
\text { private- } \\
\text { corporation }\end{array}$ & $\begin{array}{r}\text { Misc. private- } \\
\text { individual } \\
\text { farmer }\end{array}$ \\
\hline Jack pine & 42.1 & 2.1 & 7.1 & 2.4 & $\ldots$ & 30.5 \\
\hline Red pine & 50.5 & 4.8 & 14.3 & 8.8 & -- & 22.6 \\
\hline White pine & 23.6 & -- & $\cdots$ & $\cdots$ & $=-$ & 23.6 \\
\hline White spruce & 8.6 & $\cdots$ & $\cdots$ & -- & $\cdots$ & 8.6 \\
\hline Northem white-cedar & 6.0 & $\cdots$ & -- & $\cdots$ & $\cdots$ & 6.0 \\
\hline Tamarack & 7.8 & -- & -- & $\cdots$ & 3.0 & 4.8 \\
\hline Oak-hickory & 746.4 & 3.1 & 110.3 & 19.9 & 62.7 & 550.4 \\
\hline Elm-ash-soft maple & 665.1 & $\cdots$ & 37.4 & 12.3 & 79.7 & 535.7 \\
\hline Maple-birch & $1,300.9$ & 4.2 & 45.2 & 36.0 & 114.4 & $1,101.1$ \\
\hline Aspen & 121.2 & -- & 23.7 & 6.2 & $\cdots$ & 91.3 \\
\hline Paper birch & 7.0 & - & - & -- & $\ldots$ & 7.0 \\
\hline Balsam poplar & 6.9 & -- & -- & -- & $\cdots$ & 6.9 \\
\hline Nonstocked & 14.6 & - & - & $\cdots$ & - & 14.6 \\
\hline All types & $3,000.7$ & 14.2 & 238.0 & 85.6 & 259.8 & $2,403.1$ \\
\hline
\end{tabular}


Table 8.--Area of timberland by ownership class and stocking class of growing-stock trees ${ }^{1}$, Southern Lower Peninsula, Michigan, 1993

(In thousand acres)

\begin{tabular}{|c|c|c|c|c|c|c|}
\hline \multirow[b]{2}{*}{ Ownership class } & \multirow[b]{2}{*}{ All classes } & \multicolumn{5}{|c|}{ Stocking class of growing-stock trees } \\
\hline & & $\begin{array}{l}\text { Non- } 2 \\
\text { stocked }\end{array}$ & $\begin{array}{l}\text { Poorly } \\
\text { stocked }\end{array}$ & $\begin{array}{l}\text { Moderately } \\
\text { stocked }\end{array}$ & $\begin{array}{c}\text { Fully } \\
\text { stocked }\end{array}$ & $\begin{array}{c}\text { Over- } \\
\text { stocked }\end{array}$ \\
\hline National forest & 14.2 & -- & 0.6 & 4.8 & 7.0 & 1.8 \\
\hline State & 238.0 & 2.2 & 24.7 & 75.4 & 93.2 & 42.5 \\
\hline County and municipal & 85.6 & -- & 7.9 & 31.7 & 29.5 & 16.5 \\
\hline Misc. private-corporation & 259.8 & 35.1 & 59.5 & 93.8 & 57.5 & 13.9 \\
\hline Misc. private-individual/farmer & $2,403.1$ & 52.0 & 503.5 & 976.5 & 695.0 & 176.1 \\
\hline All owners & $3,000.7$ & 89.3 & 596.2 & $1,182.2$ & 882.2 & 250.8 \\
\hline
\end{tabular}

1 This table is based on the stocking percent of growing-stock trees rather than that of all live trees. To use the definitions of stocking for this table, replace the term "all live" by "growingstock."

2 Timberland insufficiently stocked with growing-stock trees.

Table 9.--Area of timberland by forest type and stand-size class,

Southern Lower Peninsula, Michigan, 1993

(In thousand acres)

\begin{tabular}{|c|c|c|c|c|c|}
\hline \multirow[b]{2}{*}{ Forest type } & \multirow[b]{2}{*}{ All stands } & \multicolumn{4}{|c|}{ Stand-size class } \\
\hline & & Sawtimber & Poletimber & $\begin{array}{c}\text { Sapling and } \\
\text { seedling }\end{array}$ & $\begin{array}{c}\text { Non- } \\
\text { stocked } \\
\end{array}$ \\
\hline Jack pine & 42.1 & 6.7 & 30.6 & 4.8 & - \\
\hline Red pine & 50.5 & 35 & 13.1 & 2.4 & $\cdots$ \\
\hline White pine & 23.6 & 12 & 5.3 & 6.3 & - \\
\hline White spruce & 8.6 & $\cdots$ & 4.9 & 3.7 & $\cdots$ \\
\hline Northern white-cedar & 6.0 & 3.0 & 3.0 & $\cdots$ & $-\cdot$ \\
\hline Tamarack & 7.8 & 3.0 & 0.7 & 4.1 & - \\
\hline Oak-hickory & 746.4 & 560.8 & 102.4 & 83.2 & $\cdots$ \\
\hline Elm-ash-soft maple & 665.1 & 388.0 & 162.6 & 114.5 & $\cdots$ \\
\hline Maple-birch & $1,300.9$ & 694.5 & 277.8 & 328.6 & - \\
\hline Aspen & 121.2 & 21.1 & 55.8 & 44.3 & -- \\
\hline Paper birch & 7.0 & $\cdots$ & $\cdots$ & 7.0 & - - \\
\hline Balsam poplar & 6.9 & $\cdots$ & 6.9 & - & -- \\
\hline Nonstocked & 14.6 & $\ldots$ & $\cdots$ & - & 14.6 \\
\hline All types & $3,000.7$ & $1,724.1$ & 663.1 & 598.9 & 14.6 \\
\hline
\end{tabular}




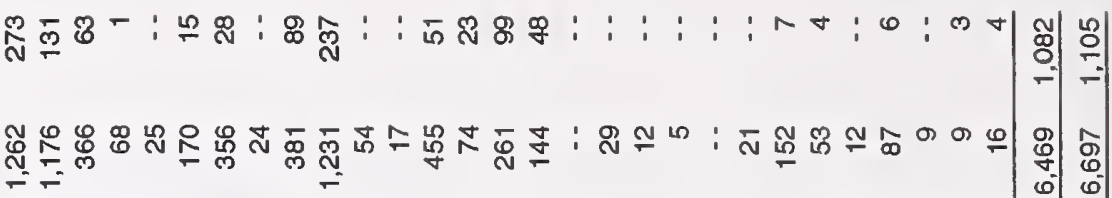

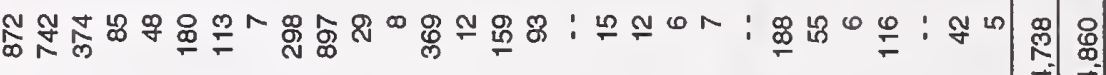

원 듄

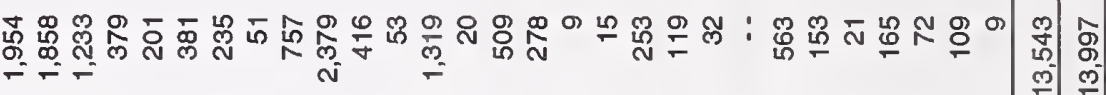

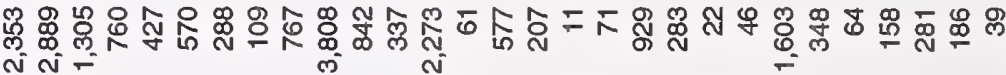
$\stackrel{\nabla}{\frac{\nabla}{6}} \underset{-\infty}{-\infty}$

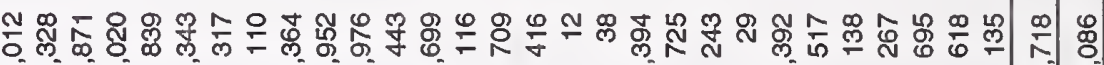

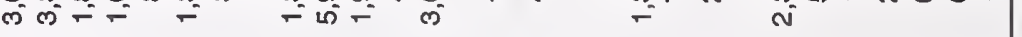
๓్

윰윤 लें

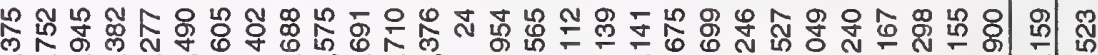

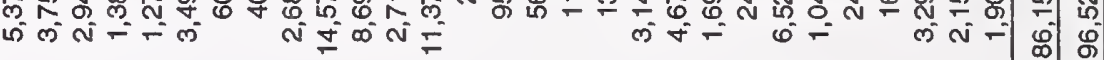

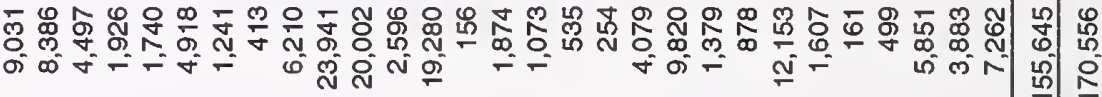

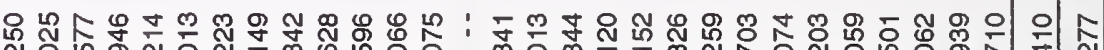

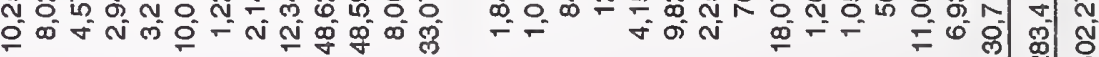

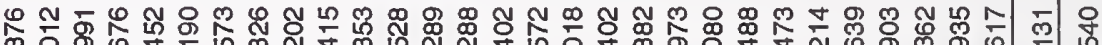
虫

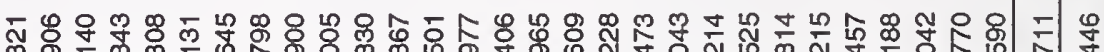

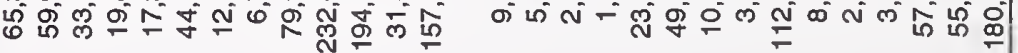

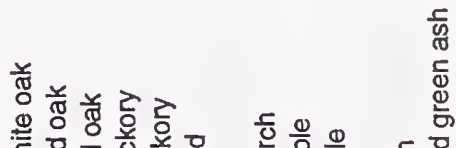

$\frac{\sqrt{5}}{\sqrt{8}}$

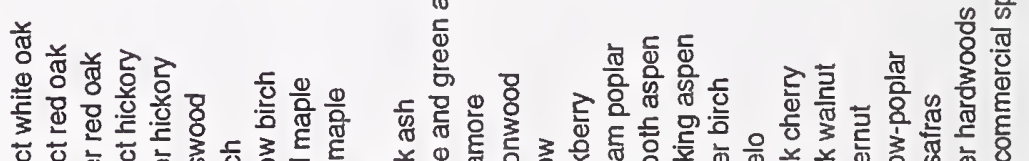

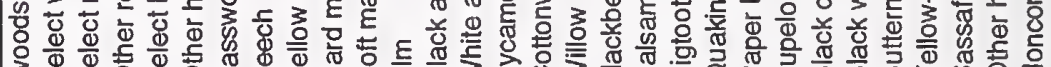
突 


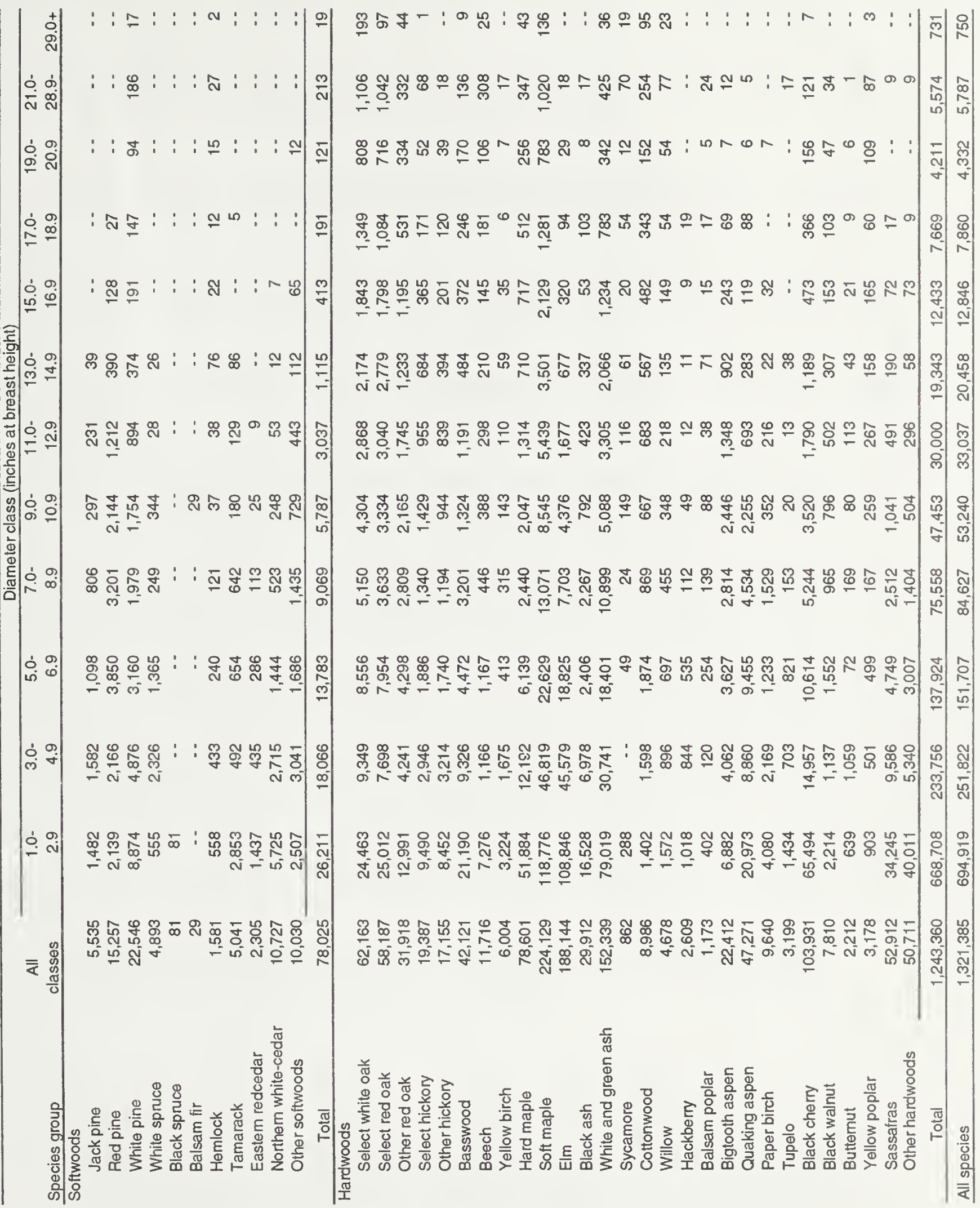


Table 13.--Net volume of growing-stock in the saw-log portion of sawtimber trees on timberland by species group and diameter class, Southem Lower Peninsula, Michigan 1993

(In thousand cubic feet)

\begin{tabular}{|c|c|c|c|c|c|c|c|c|c|}
\hline \multirow[b]{2}{*}{ Species group } & \multirow[b]{2}{*}{$\begin{array}{c}\text { All } \\
\text { classes }\end{array}$} & \multicolumn{8}{|c|}{ Diameter class (inches at breast height) } \\
\hline & & $\begin{array}{l}9.0- \\
10.9 \\
\end{array}$ & $\begin{array}{r}11.0- \\
12.9 \\
\end{array}$ & $\begin{array}{r}13.0- \\
14.9 \\
\end{array}$ & $\begin{array}{r}15.0- \\
16.9 \\
\end{array}$ & $\begin{array}{r}17.0- \\
18.9 \\
\end{array}$ & $\begin{array}{r}19.0 \\
20.9 \\
\end{array}$ & $\begin{array}{r}21.0- \\
28.9 \\
\end{array}$ & $29.0+$ \\
\hline \multicolumn{10}{|l|}{ Softwoods } \\
\hline Jack pine & 5,840 & 2,229 & 2,810 & 801 & -- & -- & -- & -- & - \\
\hline Red pine & 50,272 & 18,986 & 17,857 & 8,637 & 3,737 & 1,055 & -- & -- & -- \\
\hline White pine & 72,255 & 13,823 & 12,159 & 7,910 & 6,278 & 6,417 & 5,601 & 16,384 & 3,683 \\
\hline White spruce & 4,120 & 3,094 & 443 & 583 & -- & -- & -- & -- & -- \\
\hline Balsam fir & 357 & 357 & -- & -- & -- & -- & -- & -- & -- \\
\hline Hemlock & 9,513 & 314 & 546 & 2,005 & 697 & 651 & 977 & 3,341 & 982 \\
\hline Tamarack & 6,175 & 1,838 & 2,200 & 1,882 & - - & 255 & -- & - - & - \\
\hline Eastem redcedar & 359 & 203 & 156 & -- & -- & -- & -- & -- & -- \\
\hline Northern white-cedar & 2,852 & 1,667 & 785 & 197 & 203 & - - & -- & -- & - \\
\hline Other softwoods & 16,735 & 5,829 & 5,883 & 2,398 & 2,030 & $\cdots$ & 595 & - & - \\
\hline Total & 168,478 & 48,340 & 42,839 & 24,413 & 12,945 & 8,378 & 7,173 & 19,725 & 4,665 \\
\hline \multicolumn{10}{|l|}{ Hardwoods } \\
\hline Select white oak & 275,305 & -- & 27,931 & 34,427 & 42,019 & 42,399 & 32,733 & 69,513 & 26,283 \\
\hline Select red oak & 276,777 & -- & 31,428 & 47,578 & 44,181 & 36,555 & 31,572 & 71,479 & 13,984 \\
\hline Other red oak & 117,931 & -- & 16,909 & 19,618 & 26,845 & 16,494 & 13,591 & 19,593 & 4,881 \\
\hline Select hickory & 42,863 & -- & 9,032 & 11,667 & 9,157 & 5,989 & 2,225 & 4,599 & 194 \\
\hline Other hickory & 27,854 & -- & 8,688 & 6,580 & 5,185 & 4,483 & 1,719 & 1,199 & -- \\
\hline Basswood & 62,799 & -- & 14,004 & 9,667 & 10,425 & 9,007 & 7,872 & 9,856 & 1,968 \\
\hline Beech & 47,362 & -- & 3,747 & 4,038 & 4,057 & 6,231 & 4,984 & 21,226 & 3,079 \\
\hline Yellow birch & 4,622 & -- & 1,125 & 1,173 & 911 & 191 & 262 & 960 & - \\
\hline Hard maple & 109,765 & -- & 15,750 & 13,822 & 19,578 & 19,075 & 12,201 & 23,594 & 5,745 \\
\hline Soft maple & 354,353 & -- & 61,559 & 63,927 & 56,399 & 44,784 & 35,137 & 70,513 & 22,034 \\
\hline Elm & 39,262 & -- & 16,128 & 10,842 & 7,242 & 2,878 & 1,199 & 973 & - \\
\hline Black ash & 18,980 & - & 5,273 & 6,820 & 1,436 & 3,716 & 430 & 1,305 & -- \\
\hline White and green ash & 186,960 & -- & 38,234 & 37,950 & 32,409 & 28,157 & 15,550 & 29,619 & 5,041 \\
\hline Sycamore & 14,877 & -- & 1,495 & 1,378 & 559 & 2,229 & 602 & 5,360 & 3,254 \\
\hline Cottonwood & 70,144 & -- & 6,233 & 8,062 & 10,769 & 10,281 & 5,904 & 16,725 & 12,170 \\
\hline Willow & 19,391 & -- & 1,824 & 2,040 & 3,063 & 1,545 & 2,116 & 5,449 & 3,354 \\
\hline Hackberry & 1,207 & -- & 105 & 239 & 254 & 609 & - - & -- & -- \\
\hline Balsam poplar & 4,684 & -- & 553 & 1,294 & 385 & 607 & 262 & 1,583 & -- \\
\hline Bigtooth aspen & 44,794 & -- & 16,306 & 18,058 & 6,834 & 2,516 & 330 & 750 & $\ldots$ \\
\hline Quaking aspen & 20,670 & -- & 8,081 & 5,403 & 3,208 & 3,313 & 323 & 342 & -- \\
\hline Paper birch & 3,918 & -- & 2,489 & 394 & 744 & - - & 291 & - - & -- \\
\hline Tupelo & 1,506 & -- & 148 & 581 & -- & -- & - - & 777 & - \\
\hline Black cherry & 88,051 & -- & 22,527 & 23,785 & 13,035 & 13,484 & 7,355 & 7,152 & 713 \\
\hline Black walnut & 24,989 & -- & 6,366 & 6,316 & 4,206 & 3,612 & 2,248 & 2,241 & - \\
\hline Buttemut & 3,674 & -- & 1,571 & 963 & 675 & 201 & 194 & 70 & $-\cdot$ \\
\hline Yellow poplar & 25,580 & -- & 3,145 & 3,295 & 4,651 & 2,366 & 5,346 & 6,460 & 317 \\
\hline Sassafras & 9,989 & -- & 4,418 & 2,671 & 1,619 & 541 & -- & 740 & -- \\
\hline Other hardwoods & 6,209 & -- & 2,803 & 974 & 1,664 & 278 & - & 490 & - \\
\hline Total & $1,904,516$ & $\ldots$ & 327,872 & 343,562 & 311,510 & 261,541 & 184,446 & 372,568 & 103,017 \\
\hline All species & $2,072,994$ & 48,340 & 370,711 & 367,975 & 324,455 & 269,919 & 191,619 & 392,293 & 107,682 \\
\hline
\end{tabular}




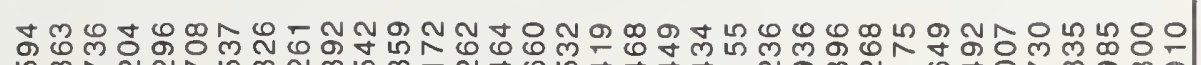

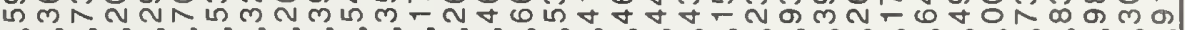
ம月の귤

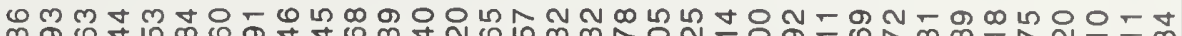

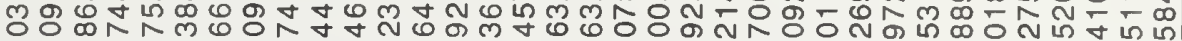

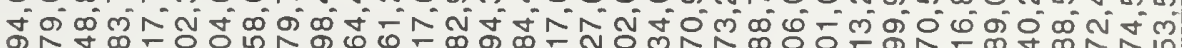

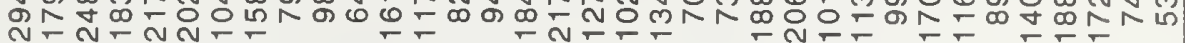

\section{스ㅇㅛㅛㅇㅛ}

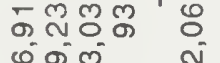

$$
\text { (n) }
$$

$$
8
$$

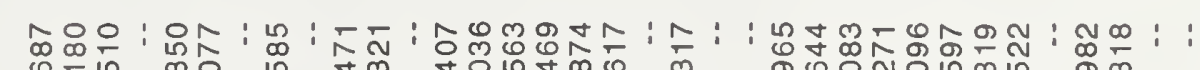

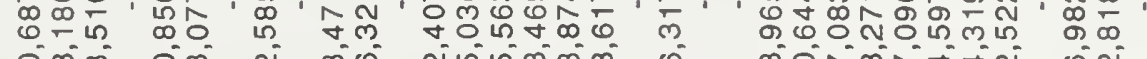

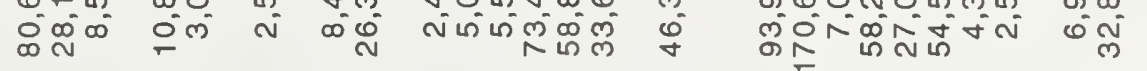

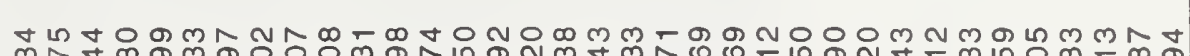

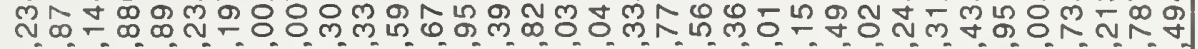

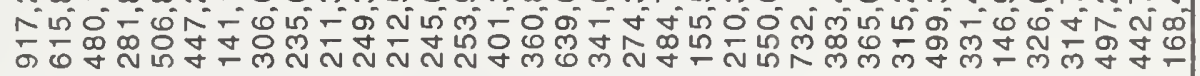
ब,

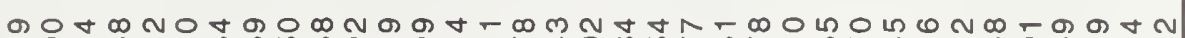

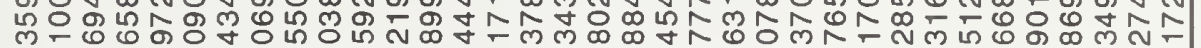

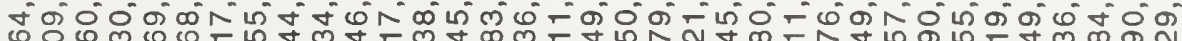

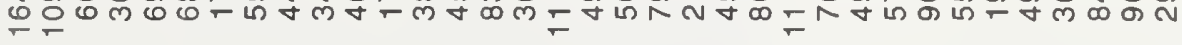

m 응

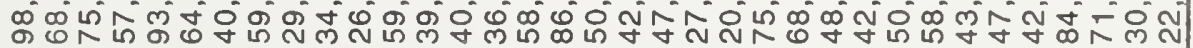

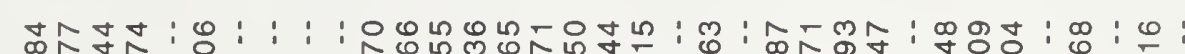

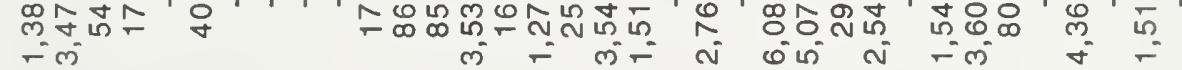

ம n

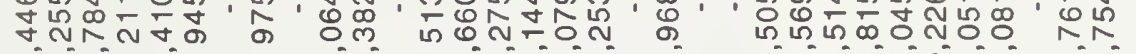

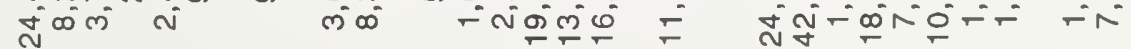

ヘ

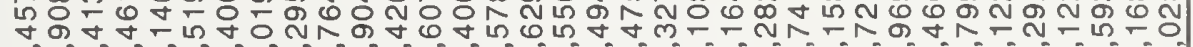

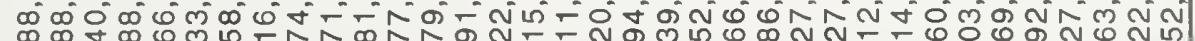
品 
Table 16.--Net volume of timber on timberland by class of timber and major species group,

Southern Lower Peninsula, Michigan, 1993

(In thousand cubic feet)

\begin{tabular}{|c|c|c|c|c|c|}
\hline \multirow[b]{2}{*}{ Class of timber } & \multirow[b]{2}{*}{$\begin{array}{c}\text { All } \\
\text { species }\end{array}$} & \multicolumn{4}{|c|}{ Species group } \\
\hline & & Pine & $\begin{array}{c}\text { Other } \\
\text { softwoods }\end{array}$ & $\begin{array}{c}\text { Soft } \\
\text { hardwoods }\end{array}$ & $\begin{array}{c}\text { Hard } \\
\text { hardwoods }\end{array}$ \\
\hline \multicolumn{6}{|l|}{ Live trees } \\
\hline \multirow{2}{*}{\multicolumn{6}{|c|}{ Growing-stock trees }} \\
\hline \multicolumn{5}{|l|}{ Sawtimber } & \\
\hline Saw log portion & $2,072,994$ & 145,022 & 23,456 & 773,890 & $1,130,626$ \\
\hline Upper stem portion & 738,883 & 22,433 & 3,340 & 302,027 & 411,083 \\
\hline Total & $2,811,877$ & 167,455 & 26,796 & $1,075,917$ & $1,541,709$ \\
\hline Poletimber & $1,426,640$ & 66,230 & 19,967 & 770,865 & 569,578 \\
\hline All growing-stock trees & $4,238,517$ & 233,685 & 46,763 & $1,846,782$ & $2,111,287$ \\
\hline \multicolumn{6}{|l|}{ Cull trees } \\
\hline Short-log trees & 125,629 & 3,337 & 682 & 54,912 & 66,698 \\
\hline \multicolumn{6}{|l|}{ Rough trees } \\
\hline Sawtimber & 136,003 & 9,401 & 1,248 & 62,460 & 62,894 \\
\hline Poletimber & 142,297 & 6,812 & 1,126 & 65,093 & 69,266 \\
\hline Total & 278,300 & 16,213 & 2,374 & 127,553 & 132,160 \\
\hline \multicolumn{6}{|l|}{ Rotten trees } \\
\hline Sawtimber & 37,487 & 546 & 584 & 20,702 & 15,655 \\
\hline Poletimber & 8,514 & 14 & 70 & 5,584 & 2,846 \\
\hline Total & 46,001 & 560 & 654 & 26,286 & 18,501 \\
\hline All cull trees & 449,930 & 20,110 & 3,710 & 208,751 & 217,359 \\
\hline All live trees & $4,688,447$ & 253,795 & 50,473 & $2,055,533$ & $2,328,646$ \\
\hline \multicolumn{6}{|l|}{ Salvable dead trees } \\
\hline Sawtimber & 18,295 & 1,908 & - & 6,883 & 9,504 \\
\hline Poletimber & 18,116 & 906 & 263 & 12,244 & 4,703 \\
\hline Total & 36,411 & 2,814 & 263 & 19,127 & 14,207 \\
\hline All classes & $4,724,858$ & 256,609 & 50,736 & $2,074,660$ & $2,342,853$ \\
\hline
\end{tabular}




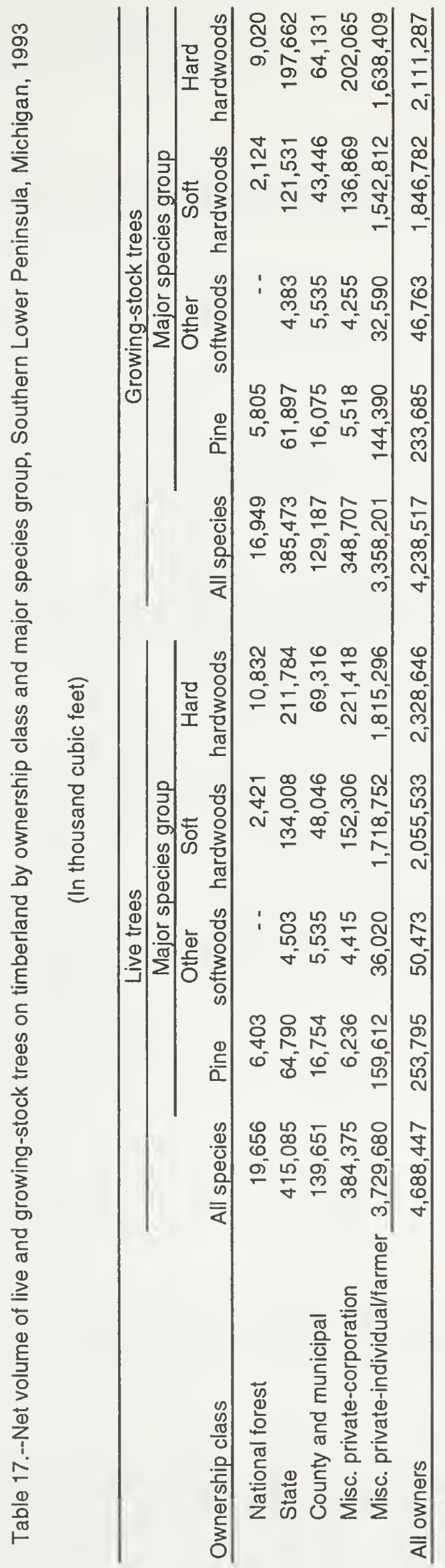




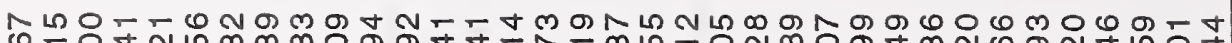

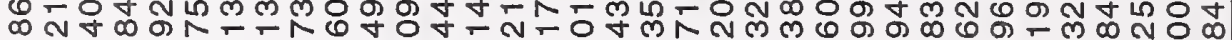

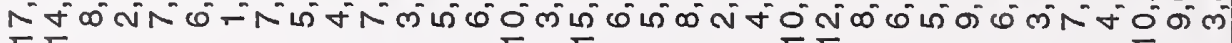

OML

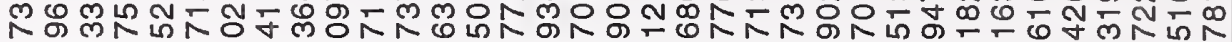

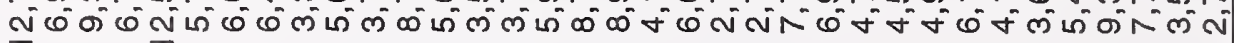
$\leftarrow$

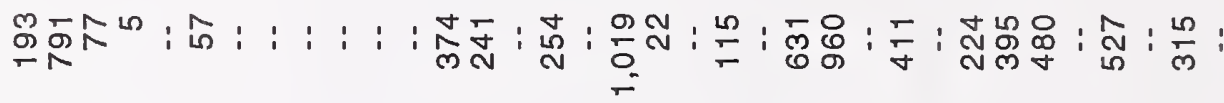

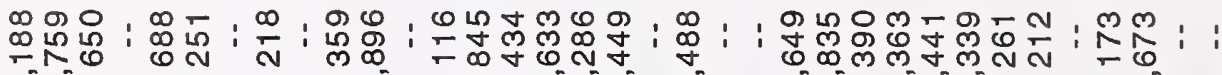
$\forall+$ लंखं

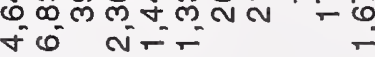

N $\infty$ N

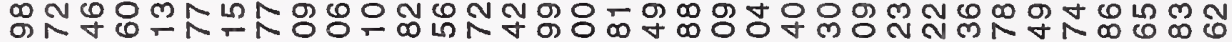

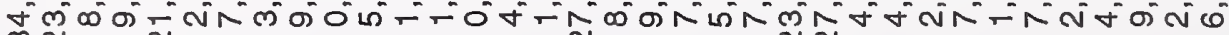

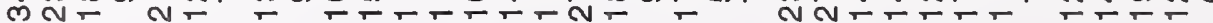

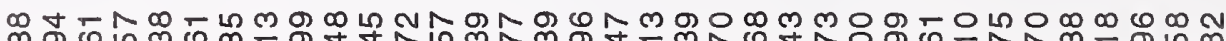
○ An

D-OLサNM-NODNONN

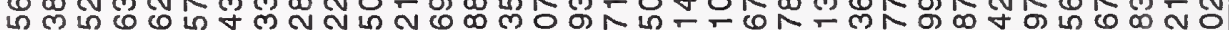

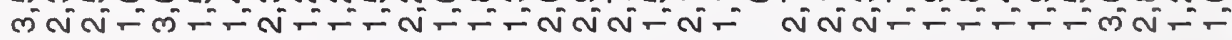

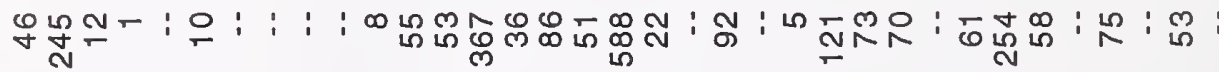

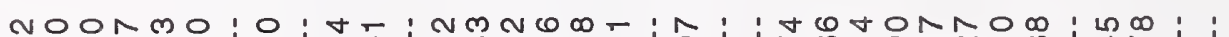

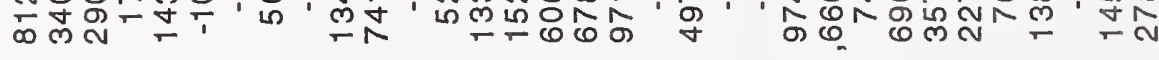

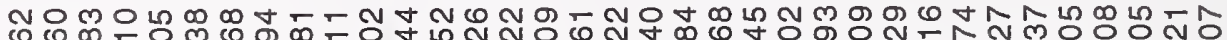

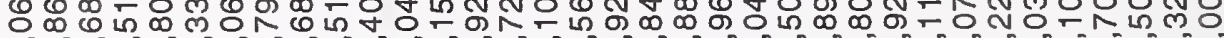

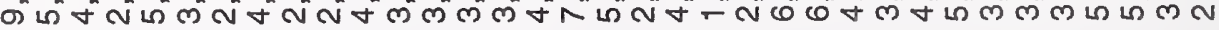




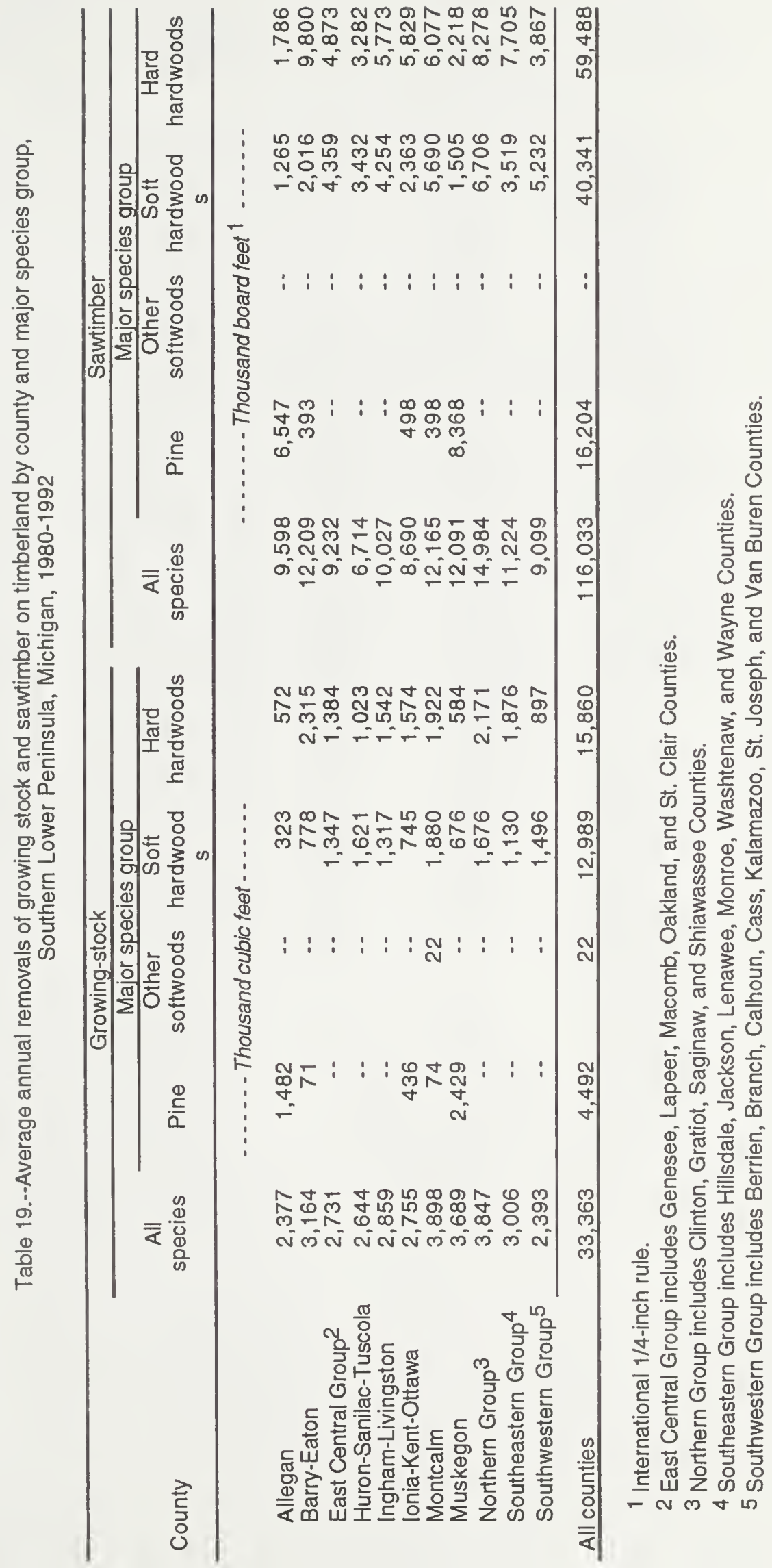


Table 20.--Average annual net growth, average annual mortality, and average annual removals of growing stock and sawtimber on timberland by species group, Southern Lower Peninsula, Michigan, 1980-1992

\begin{tabular}{|c|c|c|c|c|c|c|}
\hline \multirow[b]{2}{*}{ Species group } & \multicolumn{3}{|c|}{ Growing stock } & \multicolumn{3}{|c|}{ Sawtimber } \\
\hline & Net growth 1 & Mortality & Removals & New growth 1 & Mortality & $R \in$ movals \\
\hline \multirow{2}{*}{\multicolumn{7}{|c|}{ Softwoods }} \\
\hline & & & & & & \\
\hline & 67 & 353 & 59 & 545 & 1,078 & -- \\
\hline Red pine & 4,290 & -- & 2,447 & 17,034 & 5 & 8,124 \\
\hline White pine & 4,331 & 417 & 1,572 & 20,121 & 1,429 & 7,582 \\
\hline White spruce & 1,216 & -. & -. & 2,619 & 4 & -- \\
\hline Balsam fir & 11 & -- & -- & 55 & -- & -- \\
\hline Hemlock & 278 & 23 & -. & 1,534 & 7 & -. \\
\hline Tamarack & 387 & 326 & -- & 1,639 & 340 & -- \\
\hline Eastern redcedar & 165 & -. & -- & 110 & -- & -- \\
\hline Northern white-cedar & 333 & 36 & 22 & 1,092 & 138 & -. \\
\hline Other softwoods & 1,589 & 108 & 414 & 5,938 & 18 & 498 \\
\hline Total & 12,667 & 1,263 & 4,514 & 50,687 & 3,019 & 16,204 \\
\hline \multicolumn{7}{|l|}{ Hardwoods } \\
\hline Select white oak & 9,924 & 542 & 3,001 & 48,889 & 1,868 & 11,900 \\
\hline Select red oak & 13,192 & 1,572 & 4,253 & 60,596 & 4,104 & 18,228 \\
\hline Other red oak & 5,996 & 819 & 2,123 & 25,844 & 2,183 & 9,124 \\
\hline Select hickory & 1,918 & 444 & 324 & 7,119 & 1,376 & 1,032 \\
\hline Other hickory & 1,613 & 277 & 272 & 6,582 & 789 & 951 \\
\hline Basswood & 3,834 & 678 & 1,312 & 13,072 & 2,240 & 4,116 \\
\hline Beech & 1,808 & 141 & 792 & 9,051 & 537 & 2,738 \\
\hline Yellow birch & 135 & 206 & -- & 737 & 469 & -. \\
\hline Hard maple & 6,572 & 273 & 1,505 & 21,609 & 1,177 & 6,291 \\
\hline Soft maple & 26,571 & 2,145 & 4,002 & 89,830 & 6,536 & 15,306 \\
\hline Elm & 12,069 & 4,498 & 882 & 22,172 & 6,175 & 615 \\
\hline Black ash & 1,694 & 405 & 309 & 3,584 & 905 & 316 \\
\hline White and green ash & 18,752 & 1,525 & 2,915 & 60,182 & 3,483 & 8,616 \\
\hline Sycamore & 412 & 26 & 133 & 2,491 & 44 & 732 \\
\hline Cottonwood & 4,738 & 195 & 1,141 & 22,273 & 553 & 5,135 \\
\hline Willow & 590 & 334 & 159 & 3,075 & 981 & 512 \\
\hline Hackberry & 173 & 12 & -- & 301 & 6 & -- \\
\hline Balsam poplar & 230 & 194 & 314 & 1,439 & 528 & 689 \\
\hline Bigtooth aspen & 4,159 & 1,650 & 1,378 & 15,222 & 4,207 & 4,570 \\
\hline Quaking aspen & 4,726 & 2,228 & 1,714 & 8,397 & 1,958 & 3,376 \\
\hline Paper birch & 489 & 406 & 84 & 762 & 494 & -- \\
\hline Tupelo & 253 & 7 & 19 & 649 & 7 & 78 \\
\hline Black cherry & 8,552 & 861 & 1,317 & 21,317 & 845 & 3,789 \\
\hline Black walnut & 1,743 & 181 & 76 & 6,391 & 737 & 387 \\
\hline Butternut & 204 & 36 & -- & 1,020 & 4 & -- \\
\hline Yellow poplar & 1,332 & 63 & 225 & 6,036 & 146 & 1,107 \\
\hline Sassafras & 2,006 & 359 & 408 & 4,001 & 391 & 107 \\
\hline Other hardwoods & 1,768 & 146 & 191 & 3,052 & 41 & 114 \\
\hline Total & 135,453 & 20,223 & 28,849 & 465,693 & 42,784 & 99,829 \\
\hline All species & 148,120 & 21,486 & 33,363 & 516,380 & 45,803 & 116,033 \\
\hline
\end{tabular}

1 An estimate of average gross growth may be computed by adding average mortality to average net growth.

2 International 1/4-inch rule. 
Table 23.--Current annual net growth, current annual mortality, and 1990 removals of growing stock and sawtimber on timberland by species group, Southern Lower Peninsula, Michigan, 1992

\begin{tabular}{|c|c|c|c|c|c|c|}
\hline \multirow[b]{2}{*}{ Species group } & \multicolumn{3}{|c|}{ Growing stock } & \multicolumn{3}{|c|}{ Sawtimber } \\
\hline & $\begin{array}{c}1992 \\
\text { Net Growth } 1 \\
\end{array}$ & $\begin{array}{c}1992 \\
\text { Mortality }\end{array}$ & $\begin{array}{c}1990 \\
\text { Removals } 2 \\
\end{array}$ & $\begin{array}{c}1992 \\
\text { Net Growth } 1 \\
\end{array}$ & $\begin{array}{c}1992 \\
\text { Mortality }\end{array}$ & $\begin{array}{c}1990 \\
\text { Removals }^{2} \\
\end{array}$ \\
\hline & \multicolumn{3}{|c|}{ - . . - Thousand cubic feet - . . . - } & \multicolumn{3}{|c|}{... Thousand board feet ${ }^{3} \ldots$} \\
\hline $\begin{array}{l}\text { Softwoods } \\
\text { Jack pine }\end{array}$ & 88 & 491 & $\ldots$ & -64 & 1241 & 1 \\
\hline Red pine & 4,340 & 2 & 647 & 19,978 & 59 & 3,653 \\
\hline White pine & 5,192 & 207 & 44 & 23,187 & 645 & 256 \\
\hline White spruce & 1,610 & 9 & -- & 3,035 & 22 & 2 \\
\hline Balsam fir & -3 & 11 & -- & -13 & 51 & * \\
\hline Hemlock & 414 & 14 & -- & 2,339 & 63 & -- \\
\hline Tamarack & 432 & 91 & -- & 2,756 & 203 & -- \\
\hline Eastern redcedar & 210 & 3 & -- & 128 & 1 & -- \\
\hline Northern white-cedar & 403 & -- & -- & 738 & 18 & 2 \\
\hline Other softwoods & 1,922 & 17 & -- & 7,136 & 54 & -- \\
\hline Total & 14,608 & 845 & 691 & 59,220 & 2,357 & 3,914 \\
\hline \multicolumn{7}{|l|}{ Hardwoods } \\
\hline Select white oak & 11,378 & 81 & 2,839 & 53,263 & 892 & 11,305 \\
\hline Select red oak & 12,203 & 2,093 & 7,135 & 57,710 & 5,350 & 33,588 \\
\hline Other red oak & 5,486 & 1,214 & -- & 26,112 & 3,210 & -. \\
\hline Select hickory & 2,033 & 354 & 392 & 7,976 & 1,034 & 2225 \\
\hline Other hickory & 1,593 & 241 & -- & 5,568 & 576 & \\
\hline Basswood & 3,697 & 731 & 453 & 10,009 & 2,201 & 2,367 \\
\hline Beech & 1,814 & 183 & 245 & 9,259 & 694 & 1,337 \\
\hline Yellow birch & 360 & 85 & 1 & 848 & 214 & 21 \\
\hline Hard maple & 6,366 & 479 & 925 & 20,574 & 1,338 & 5,240 \\
\hline Soft maple & 26,987 & 2,688 & 2,912 & 80,822 & 7,675 & 13,086 \\
\hline Elm & 14,580 & 3,406 & 112 & 33,313 & 6,279 & 621 \\
\hline Black ash & 1,881 & 322 & 1,426 & 3,191 & 812 & 7,315 \\
\hline White and green ash & 21,977 & 1,360 & ** & 69,222 & 2,355 & * * \\
\hline Sycamore & 536 & 64 & -- & 2,899 & 294 & -- \\
\hline Cottonwood & 4,106 & 418 & 465 & 20,458 & 1,638 & 2,413 \\
\hline Willow & 898 & 129 & -- & 2,959 & 395 & -- \\
\hline Hackberry & 120 & 24 & -- & 186 & 27 & -- \\
\hline Balsam poplar & 358 & 156 & 19 & 2,091 & 486 & 101 \\
\hline Bigtooth aspen & 4,915 & 1,571 & 1,590 & 21,352 & 3,633 & 4,953 \\
\hline Quaking aspen & 4,900 & 2,090 & *** & 12,412 & 2,142 & $* * *$ \\
\hline Paper birch & 789 & 170 & 26 & 1,310 & 242 & 131 \\
\hline Tupelo & 270 & 30 & -- & 564 & 52 & .. \\
\hline Black cherry & 8,122 & 799 & -. & 24,970 & 1,289 & -- \\
\hline Black walnut & 1,551 & 148 & -- & 6,127 & 375 & -- \\
\hline Butternut & 272 & 21 & -- & 1,796 & 56 & -- \\
\hline Yellow-poplar & 1,086 & 92 & -. & 4,855 & 347 & -- \\
\hline Sassafras & 2,345 & 516 & -- & 4,575 & 573 & -- \\
\hline Other hardwoods & 1,714 & 251 & 1,093 & 3,098 & 331 & 5,547 \\
\hline Total & 142,337 & 19,716 & 19,633 & 487,519 & 44,510 & 90,250 \\
\hline All species & 156,945 & 20,561 & 20,324 & 546,739 & 46,867 & 94,164 \\
\hline
\end{tabular}

1 An estimate of current gross growth may be computed by adding current mortality to current net growth.

2 Based on mill survey data (Hackett and Pilon 1993). For the Southern Lower Peninsula, 1990 is the most current mill survey.

${ }^{3}$ International $1 / 4$ inch rule.

* Removals for the black spruce species group are included in the removals for white spruce.

** Removals for the white and green ash species group are included in the removals for black ash.

* * Removals for the quaking aspen species group are included in the removals for bigtooth aspen. 
Table 24.--Net volume of sawtimber trees on timberland by species group and butt log grade or tree grade, Southern Lower Peninsula, Michigan, 1993

(In thousand board feet) ${ }^{1}$

\begin{tabular}{|c|c|c|c|c|c|}
\hline \multirow[b]{2}{*}{ Species } & \multirow[b]{2}{*}{$\begin{array}{c}\text { All } \\
\text { grades }\end{array}$} & \multicolumn{4}{|c|}{ Butt log grade } \\
\hline & & 1 & 2 & 3 & $\begin{array}{c}\text { Tie } \\
\text { and timber }\end{array}$ \\
\hline \multicolumn{6}{|l|}{ Softwoods } \\
\hline Jack pine & 33,556 & -. & -- & 33,556 & -. \\
\hline Red pine & 285,654 & -- & -. & 285,654 & .. \\
\hline White pine & 437,179 & 25,364 & 20,484 & 330,786 & 60,545 \\
\hline White spruce & 24,342 & ,. & -. & 24,342 & -- \\
\hline Balsam fir & 2,003 & .- & -- & 2,003 & -. \\
\hline Hemlock & 59,598 & .. & 8,675 & 50,923 & -. \\
\hline Tamarack & 35,871 & .- & 22,577 & 13,294 & .. \\
\hline Eastern redcedar & 2,211 & -. & . & 2,211 & -. \\
\hline Northern white-cedar & 17,308 & -. & -- & 17,308 & -- \\
\hline Other softwoods & 96,372 & -- & -- & 96,372 & .. \\
\hline \multirow[t]{2}{*}{ Total } & 994,094 & 25,364 & 51,736 & 856,449 & 60,545 \\
\hline & & \multicolumn{4}{|c|}{ Tree grade } \\
\hline Species & $\begin{array}{l}\text { All } \\
\text { grades }\end{array}$ & 1 & 2 & 3 & $\begin{array}{c}\text { Tie } \\
\text { and timber }\end{array}$ \\
\hline \multicolumn{6}{|l|}{ Hardwoods } \\
\hline Select white oak & $1,747,301$ & 325,170 & 569,874 & 655,557 & 196,701 \\
\hline Select red oak & $1,749,079$ & 398,618 & 462,392 & 533,336 & 354,733 \\
\hline Other red oak & 740,840 & 129,416 & 225,124 & 229,676 & 156,625 \\
\hline Select hickory & 268,263 & 20,896 & 69,277 & 140,307 & 37,784 \\
\hline Other hickory & 173,800 & 36,197 & 35,436 & 63,606 & 38,560 \\
\hline Basswood & 396,138 & 136,601 & 144,253 & 115,284 & -. \\
\hline Beech & 307,417 & 42,502 & 70,882 & 132,009 & 62,024 \\
\hline Yellow birch & 29,342 & .. & 3,892 & 20,711 & 4,739 \\
\hline Hard maple & 699,734 & 303,208 & 177,106 & 171,030 & 48,389 \\
\hline Sott maple & $2,264,188$ & 158.004 & 612,550 & $1,033,176$ & 460,457 \\
\hline Elm & 248,094 & 11,799 & 49,029 & 163,200 & 24,066 \\
\hline Black ash & 118,519 & .. & 51,290 & 63,359 & 3,870 \\
\hline White and green ash & $1,164,386$ & 307,010 & 417,129 & 356,020 & 84,227 \\
\hline Sycamore & 97,233 & 24,235 & 34,779 & 38,218 & .. \\
\hline Cottonwood & 447,716 & 93,142 & 101,562 & 201,283 & 51,729 \\
\hline Willow & 124,439 & 5,020 & 45,854 & 48,051 & 25,514 \\
\hline Hackberry & 7,544 & 4,416 & .. & 3,128 & - \\
\hline Black poplar & 29,464 & 6,734 & 3,970 & 15,105 & 3,655 \\
\hline Bigtooth aspen & 276,641 & .. & 45,743 & 127,472 & 103,426 \\
\hline Quaking aspen & 128,374 & 13,499 & 11,173 & 64,122 & 39,581 \\
\hline Paper birch & 24,655 & . & -. & 24,655 & -. \\
\hline Tupelo & 9,385 & .- & .- & 9,385 & .- \\
\hline Black cherry & 554,057 & 76,641 & 167.670 & 283,033 & 26,714 \\
\hline Black walnut & 157,291 & 31,645 & 71,144 & 49,118 & 5,384 \\
\hline Butternut & 22,990 & .. & 19,167 & 3,823 & .. \\
\hline Yellow poplar & 162,735 & 57,285 & 32,572 & 63,203 & 9,676 \\
\hline Sassafras & 62,292 & 8,705 & 12,184 & 41,404 & -. \\
\hline Other hardwoods & 38,507 & -- & 6,886 & 19,771 & 11,850 \\
\hline Total & $12,050,424$ & $2,190,744$ & $3,440,937$ & $4,669,041$ & $1,749,702$ \\
\hline All species & $13,044,518$ & $2,216,108$ & $3,492,673$ & $5,525,490$ & $1,810,247$ \\
\hline
\end{tabular}

${ }^{1}$ International $1 / 4$-inch rule. 


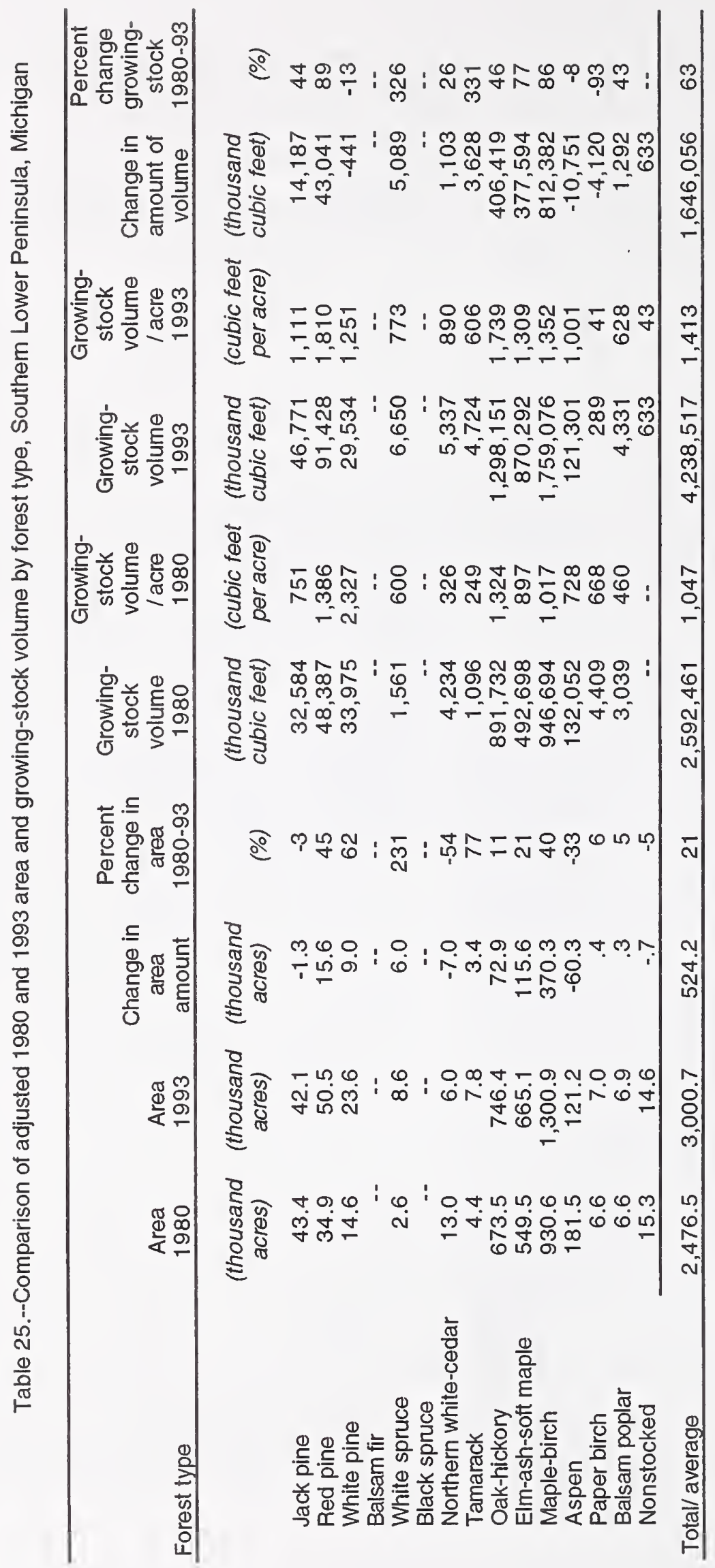


Schmidt, Thomas L.

1993. Forest statistics for Michigan's Southern Lower Peninsula Unit, 1994. Resour. Bull. NC-155. St. Paul, MN: U.S. Department of Agriculture, Forest Service, North Central Forest Experiment Station. 46 p.

The fifth inventory of Michigan's Southern Lower Peninsula forests reports $14,429.0$ thousand acres of land, of which 3,053.7 thousand acres are forested. This bulletin presents statistical highlights and contains detailed tables of forest area, as well as timber volume, growth, removals, mortality, and ownership.

KEY WORDS: Forest area, timber volume, growth, removals, mortality. 
Our job at the North Central Forest Experiment Station is discovering and creating new knowledge and technology in the field of natural resources and conveying this information to the people who can use it. As a new generation of forests emerges in our region, managers are confronted with two unique challenges: (1) Dealing with the great diversity in composition, quality, and ownership of the forests, and (2) Reconciling the conflicting demands of the people who use them. Helping the forest manager meet these challenges while protecting the environment is what research at North Central is all about.

MORTH CENTRE 